\title{
SCYTHIA AS REFLECTED BY IORDANES (JORDANES): A SCENE FROM THE SIXTH CENTURY*
}

\author{
Abdullah ÜSTüN**
}

\begin{abstract}
This study focuses on Scythia, Iordanes' Scythia, as depicted in his work entitled Getica. The first question of the study is how Iordanes saw Scythia. Although his records about physical geography are discussed here, the main focus will be on his descriptions of human geography/ethnography. In his human geography narratives, emphasis will be on Eastern Scythia tribes such as the Huns and the Bulgars which have been less emphasized in the previous studies. The second question of the study is where Scythia is according to Iordanes. Therefore, the way that Iordanes positions Scythia will be discussed in order to gain insight into his perception of Scythia. These processes will be included comparisons with Iordanes' other work Romana and other texts written before him and or by his contemporaries. In this way, the examination is expected to contribute to our understanding of Iordanes' text and the geographical and the historical knowledge in the sixth century.
\end{abstract}

Keywords: Iordanes (Jordanes), Getica, Scythia, Huns, Bulgars, Acatziri, Historical geography.

\section{$\ddot{O} z$}

\section{Iordanes'in Gözünden Scythia: Altıncı Yüzyıldan Bir Sahne}

Bu çalışma Iordanes'in Getica adlı eserinde tasvir ettiği Scythia'yı, Iordanes'in Scythia'sını konu edinmektedir. Çalışmanın ilk sorusu, Iordanes'in nazarında Scythia'nın nasıl bir yer olduğudur. Burada fiziki coğrafya hakkındaki kayıtları ele alınmakla birlikte asıl ilgi beşerî coğrafya, etnografya tasvirlerinde olacaktır. Beşerî coğrafya anlatıları içinde, araştırmalarda daha az üzerinde durulan, Hun, Bulgar gibi Doğu Scythia kabileleri daha ön planda tutulacaktır. Çalışmanın ikinci sorusu Iordanes'e göre Scythia'nın neresi olduğudur. Burada Iordanes'in Scythia'y1 konumlandırması ele alınacaktır. Böylelikle Iordanes'in mekân tasavvuru anlaşılmaya çalış1lacaktır. Bu süreçlere, Iordanes'in diğer eseri Romana ve kendinden önce ve kendi devrinde

\footnotetext{
* This study was conducted with contributions from scientific research project number " 16 TDAE004", supported by Ege University. Therefore, I would like to thank the relevant institutions and individuals. I would also like to extend my thanks to Neriman Karakoç and Jacki Gözen, lecturers at Ege University, who translated the study into English.

** Asst. Prof., Ege University Institute of Turkish World Studies, İzmir.

E-mail: abdustun@gmail.com. ORCID: 0000-0003-0977-4902

(Makale Gönderim Tarihi: 09.01.2020 - Makale Kabul Tarihi: 29.06.2020)
} 
yazılmış metinlerle karşılaştırması dahil edilecektir. Çalışmadan gerek Iordanes'in metinlerinin gerek altıncı yüzyılın tarih ve coğrafya bilgisinin anlaşılmasına bir nebze de olsa katk1 yapması beklenmektedir.

Anahtar kelimeler: Iordanes, Getica, Scythia (İskit), Hunlar, Bulgarlar, Acatziri, Tarihi coğrafya.

Two Scythias appear in Iordanes: magna Scythia and minor Scythia. Iordanes explains the relationship between the two by stating that the name of Scythia minor was taken from the former -Scythia magna. ${ }^{1}$ He presents data concerning the position of minor Scythia in Romana. While defining the army which Attila recruited, first he addresses the part of this army related to Gepids and Goths; following this, he states that there were many more nations in this army which plundered both Illyricum \& Thracia and Dacia, Moesia (Mysia), and Scythia. ${ }^{2}$ The order of these toponyms gives the impression that Iordanes's listing was from west to east along the Balkans. If that is the case, (minor) Scythia lies on the east of Moesia and Dacia. Furthermore, considering that it was one of the Roman provinces which was plundered, it is a place which is mentioned like Illyricum, Thracia, Moesia and Dacia. ${ }^{3}$ In Getica, on the other hand, we see Scythia Minor as a place conquered with Moesia inferior by Alani under the leadership of $\mathrm{Candac}^{4}$ and also as a place which Attila's younger son Irnek (Hernac) preferred the farthest region of to settle with his followers. ${ }^{5}$ As Iordanes stated, the name of this place was taken from the other. Therefore, the dichotomy arises from this quotation. For the purpose of this study, this means that the term Scythia has two connotations for Iordanes.

What kind of a place is Scythia?

This study focuses on the questions of what kind of a place magna Scythia is and where it is in the eyes of Iordanes. While the Scythia issue, which stands like a subtopic of geography topics in Getica, constitutes the general framework of this study, the priority will be on the eastern peoples of Scythia, who have had a less emphasized focus in previous studies on this topic. In the mentioned section a plain definition of Iordanes for Scythia is longe se tendens lateque aperiens a long and extensive place. ${ }^{6}$ Iordanes's Scythia means more than somewhere ordinary for himself and for Goths inasmuch as Iordanes wrote Getica in order to

\footnotetext{
${ }^{1}$ Iordanes Getica 62: a magna Scythia nomen mutuatum minor Scythia appellatur

${ }^{2}$ Iordanes Romana 331: omnem Illyricum Thraciamque, et utramque Daciam, Moesiam et Scythiam populatus est

${ }^{3}$ Iordanes reuses the term Scythia in Romana 321 and 357 but this time only to characterize the two people named Rodagius and Vitalianus so that there will not be any possibilities of geographical implications.

${ }^{4}$ Iordanes Getica 265.

${ }^{5}$ Iordanes Getica 266

${ }^{6}$ Iordanes Getica 31, The part defined as Scythia 'Chapter' Getica 30-37.
} 
tell the story of the Goths. ${ }^{7}$ In this sense, he presents Scythia as an area having a large amount of wealth delectatus magna ubertate regionum ${ }^{8}$ which pleased Goths who were searching for available lands happy locaquae dum quereret congrua. ${ }^{9}$ In Getica, Scythia in the eyes of the Huns is presented in a way resembling that of the Goths. Seeing Scythia for the first time, the Hunnic hunters admiratione ducti terrae Scythicae admire it and commend it Scythiam laudant to their community. ${ }^{10}$ When the expressions in the two narratives are listed, the description of Scythia emerges as favorable for settlement, wealthy, admirable, and commendable.

As well as those descriptions of Scythia in general, Iordanes also made various descriptions of certain parts. Among them there stand the ones he told about the two 'edges' of Scythia. By making the reference of "it is said" ut fertur, Iordanes expresses that the region offering passage to Scythia for the Goths is surrounded by quaking marshes and a chasm ${ }^{11}$, which makes it inaccessible quem utraque confusion natura reddidit inpervium. Iordanes, this time by making a reference to travelers, explains that they relayed what they heard from afar, and adds that according to the travelers it is still possible to find traces of people here: "Verumtamen hodieque illic etvoces armentorum audiri et indicia hominum depraehendi commeantium attestationem, quamvis a longe audientium, credere licet". Thus, it becomes clear that travelers are also among the sources which he used for his work. However, this statement shows us more than that because Iordanes discusses to what extent the travelers can know the topic in question. Furthermore, he narrows down his depiction about this part of Scythia to two dimensions: his own period as the time, and the area Goths entered Scythia as the place. Where the Huns entered Scythia was also a marsh beyond which they thought no one lived. This time, the name of the marsh is clear: Maeotis palus ${ }^{12}$,

\footnotetext{
${ }^{7}$ Iordanes Getica 1.

${ }^{8}$ Iordanes Getica 27.

${ }^{9}$ It must be noted that in Getica it is claimed that Iordanes entered into an argument with Procopius over the policy of Roman Empire towards 'Barbarians', especially Goths. In this sense, it is claimed that Iordanes wanting to explain why Goths did not have another probable place to settle emphasized that Scandza was cold and Scythia was crowded. However, the Goths mentioned in this argument are the ones who left Scythia before and the argument is about why they cannot get back to Scythia. In other words, it is an independent question from Scythia's place in the eyes of Iordanes and the Goths. Goffart 1980, p. 93; For the Procopius-Iordanes relationship to be discussed in this context see Curta 1999, p. $326 \mathrm{ff}$.

${ }^{10}$ Iordanes Getica 125.

${ }^{11}$ Iordanes Getica 27: Nam is locus ... tremulis paludibus voragine circumiecta concluditur.

12 The Sea of Azov: Today's names like this one used in this study do not have any intentions of identification, they aim to make the reading of the study easier. Except for the most commonly used ones, the form in the text was taken as the base to which the today's names are referred. In Mommsen edition this name is also recorded as Maeotis: Meotis (45) 65/12, Meotidis (30) 61/15,
} 
and the time is specified as period two hundred years before the age of Iordanes. Additionally, Iordanes is not the composer or compiler of the second narrative, which also includes physical obstacles - a marsh - in another part of Scythia, in the direction from which the Huns came, but in fact he only cites it. ${ }^{13}$ In the end, it is clear that he intended to point out an obstacle for the Huns, who entered Scythia from another point. Iordanes seeks an explanation for this migration in the hostility ${ }^{14}$ that the evil spirits of the Huns' ancestors bear towards the Scythians..$^{15}$ It is a noteworthy fact that the first group to arrive in Scythia by overcoming the obstacles at the "edges" of Scythia and gained dominance was

(44) 65/10, Meotidem (38) 63/17, (39) 64/5, Meotidae (123) 89/20, Meotidam (124) 90/3, (125) 90/6, Meotida (30) 61/15, (32) 62/8, (117) 88/12, (123) 89/17, Meotidarum (206) 111/5, (38) $63 / 17$, (44) $65 / 10$, (117) 88/12, (123) 89/17 ve (124) 90/3. Iordanes mentions this place as 'palus' M[a]eotis in Getica 38, 44, 117, 123, 124 and 206 five times in total. Palus means bataklik or havuz in Turkish, in English it is; a swamp, marsh, morass, bog, fen, pool, in Russian it is болото and it is marais in French. All those words in different languages have still the same common meaning 'marsh'. For Russian see Skrzhinskaia 2001, p. 200, endnote 100 she says that it means a marsh but states that he translated it as 'lake'. For French see. Devillers 1995, s. 16, 18; For English see http://www.perseus.tufts.edu/hopper/morph?l=palus\&la=la\#lexicon). Iordanes records that the deepest point of Maeotis which he persistently named marsh palus is eight ulna cubit -between $3.68 \mathrm{~m}$. and $4.22 \mathrm{~m}$. in metric system- and its circumference is 144 thousand steps, passuum mil. Cxliiii, in metric system it is about $216 \mathrm{~km}$. The question of whether these sizes refer to a sea, a lake or a marsh; and also focusing on the concept of palus in the eyes of Iordanes is beyond the scope of this study. Thus, leaving these issues out, in this study I will use palus as marsh and define Maeotis as a marsh. Metric system equivalents were taken from Skrzhinskaia 2001, p. 200, endnote 100 and 101. In such references made to Mommsen edition the number in paranthesis ( ) shows the passage number in Getica, the first number after that shows the page in Mommsen, the number after aphostrophe shows the line.

${ }^{13}$ The source of which is thought to be Eunapius, (Thompson 2008, p. 32-33; Moravcsik 1958, p. 261 and 511) the narrative that mentions the Huns entering Scythia - a place they knew nothing about - guided by a deer takes place in 5th century Sozomenus Historia Ecclesiastica VI. 37 and Iordanes's contemporary, Procopius (de Bellis VIII. 5. 7-11.). Also, Iordanes when starting this narrative clearly refers to Priscus ut Priscus istoricus refert (Getica 123). Lastly, apart from the one Iordanes employed there is one more version of this narrative. In this version which Sozomenus narrated, the plot remains the same but cattle and shepherd substitute for the hunter and deer. For an interpretation study about this narrative, see Üstün 2013, p. 91-100.

${ }^{14}$ Iordanes Getica 124: Quod, credo, spiritus illi, unde progeniem trahunt, ad Scytharum invidia id egerunt. For the narrative of the Huns entering Scythia see Getica 123-125.

${ }^{15}$ Iordanes explains the origins of Huns as follows: Now in Scythia, among the Goths the kings find witches magamulier called 'haliurunnae' in their own language and banish them to a solitary place. The evil spirits spiritus inmundi see the women (witches) strolling around the area and have intercourse with them, as a result of this Huns came into existence. Iordanes clearly states that this narrative is not his own, but he cited it from ancient people ut refert antiquitas. Perhaps this source should have the potential of citing a Gothic word 'haliurunnae'. Getica 121-122. Procopius thinks that the deer which the hunters followed appears to bring evil to the people

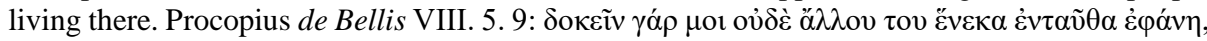

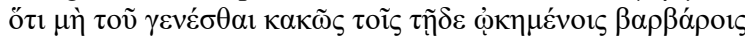


the Goths, who are the theme of Getica, and the second group is the Huns, who defeated the Goths and established their own reign. Thus, both the Goths' domination in Scythia and their fall are presented in a context at least evoking extraordinariness.

Coming to the center from the edges, it is seen that Iordanes depicts the middle of Scythia as the place where Asia and Europe diverge. ${ }^{16}$ This line comprises the Riphaei mountains ${ }^{17}$, the Tanais river $^{18}$ and Maeotis in an order. ${ }^{19}$ He mentions the Asian and European border once more without referring to Scythia using the three factors: the Riphaei mountains, Maeotis and the Tanais. He talks about the fame of the Tanais because it forms the border between Asia and Europe, later indicating that the Tanais is the only river in Scythia which never freezes, and he adds Scythia to this narration. ${ }^{20}$ Afterwards, he describes the Danaper ${ }^{21}$ as a river which originates from a large marsh, has drinkable water until halfway from the source, has some sections that are favorable for transportation, and flows into the Black Sea. He adds that the area between the

${ }^{16}$ Iordanes Getica 32: Scythiae medium est locus, qui Asiam Europamque ab alterutro dividit.

${ }^{17}$ As it is seen in Iordanes' narrative - a mountain range in northern Scythia. However, the place the narrative indicates, at least the place where the Tanais is born seems like mid Russia. In Mommsen edition this name - apart from the form of Rhipaei montes (Riphei montes) - is also recorded as follows: Rifeus (55) 69/6. The note about Riphaei mountains below presents a general view for the Antique age authors' perceptions of the Riphaei mountains: Each one of some Antique age authors believe in the existence of the Riphaei or Rhipaei mountains -the mountains which are said to be in the north of Europe by Homeros, e.g. Strabon rejects this, locate these mountains in different places: Aishulos and Pindaros claim that they are in the area where Danube originates; Posidonios of Apameia says that these mountains are the Alps; and Aristoteles locates it in Scythia and the Roman poets think that they are in the northeast part of the known world. Devillers 1995, p. 134, endnote 52. In such references made to the Mommsen edition the number in parenthesis ( ) shows the passage number in Getica, the first number after that shows the page in Mommsen, the number after apostrophe shows the line.

18 Also Thanais in the Mommsen edition: Thanais (32) 62/8. (45) 65/10. (45) 65/11.

${ }^{19}$ Iordanes Getica 32. Cf. Orosius Historia Adversus Paganos I. 2. 4. Riphaci montes ...Tanaim fluvium fundunt qui ...Maeotidas auget paludes. Orosius do not mention Scythia when presenting the Asia-Europe border; more precisely, when describing the land border of Europe.

${ }^{20}$ Iordanes Getica 45: Thanain vero hunc dico, qui ex Ripheis montibus deiectus adeo preceps ruit, ut, cum vicina flumina sive Meotis et Bosforus gelu solidentur, solus amnium confragosis montibus vaporatus, numquam Scythico duriscit algore. Cf. Pomponius Mela de Chorographia I. 115: ipse Tanais ex Riphaeo monte deiectus, adeo praeceps ruit, ut, cum vicina flumina tum Maeotis et Bosphorus tum Ponti oliqua brumali rigore durentur, solus aestus hiememque iuxta ferens idem semper et subsimilis incitatusque decurrat. Mela in his depiction does not give a place to Scythia.

${ }^{21}$ Dnieper; In the Mommsen edition this name is recorded as these forms: Danaper (30) 61/14, (35) 63/4, (46) 65/15, Borysthenes qui et Danaper (44) 65/9, Boristhenes (32) 62/4, Danaber Hunnis Var (269) 127/19 and Danaber praeterea (54) 68/17. 
two rivers is a large terrain covered in marshes and forests. ${ }^{22}$ Therefore, we come across a physical geography description in which there are marshes not only in the outer parts of Scythia but also in the central regions.

Iordanes helps us understand his perception of Scythia's physical geography with his depictions of the Caucasus ${ }^{23}$ mountain range beyond the rivers. Starting from a point a lot far away from Scythia, from ab Indico mare this mountain range curls toward Syria in Syriam curvato Angulo reflexus. Towards the north it reaches Scythia, drawing a big curve: Tunc in boream revertens Scythicas terras iugus antefatus magnis flexibus pervagatur. Here it feeds the rivers Araxes, Cysus ${ }^{24}$ and Cambises ${ }^{25}$, which flow into the Caspium mare and the mountain range reaches Riphaei. From there, forming borders to the Scythia tribes with its side, it goes down to Pontus: Indeque Scythicis gentibus dorso suo terminum praebens ad Pontum usque discendit. Its peaks feed the waters of (H)Ister. These mountains are divided into two by Ister and are called Taurus in Scythia “amne scissus dehiscens Scythia quoque Taurus vocatur”. Iordanes's Caucasus is not identical to the Caucasus mountains lying between the Black Sea and the Caspian Sea stated in today's geographic knowledge, neither is it identical to the mountains which his contemporary Procopius defines as stretching to Illiricum and Thracia. ${ }^{26}$

Indicating that he will firstly ${ }^{27}$ discuss the place where the Gepidae people live, which is surrounded by 'famous rivers' in the west of Scythia, Iordanes starts his narrative in the form of the human geography of Scythia of his own age by using the physical geographical elements. ${ }^{28} \mathrm{He}$ states that these famous rivers are Tisia ${ }^{29}$ in the north and northwest of Gepida, Danubius in the southwest, Flutausis $^{30}$ and Ister in the east. Just in the following part of this passage, he indicates that these rivers are in Dacia, which the Alpis mountains wrap like a

\footnotetext{
22 Iordanes Getica 46. Cf. Pomponius Mela de Chorographia II. 6-7 and II. 98.

${ }^{23}$ In the Mommsen edition this name is recorded as follows: Caucasus 61/16. 68/6. Cauchasus (50) 67/14. (55) 69/6.

${ }^{24}$ One of the branches of the river Aras, modern Kura river.

25 The Kura river itself or a branch of it in Albania (Jora/Jori).

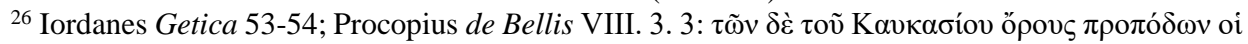

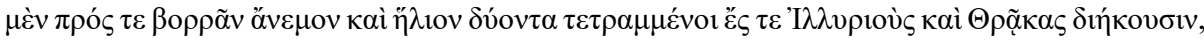

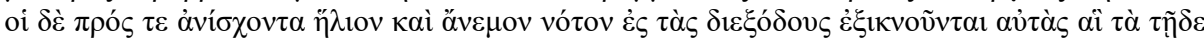

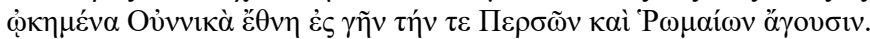

${ }^{27}$ Iordanes Getica 33: In qua Scythia prima ab occidente gens residet Gepidarum.

${ }^{28}$ Iordanes Getica 33-37.

${ }^{29}$ Tis(z)a, which originates at the Ukraine-Romania border and which joins the Danube river after passing through eastern Hungary.

${ }^{30}$ It is mentioned again in Getica 74, Aluta (Olt/u) river in mid Romania. The relationship of Ister - Danubius will be dealt with below.
} 
crown. ${ }^{31}$ In that case, Dacia appears to be part of Scythia as well. However, it is understood that here, by the term Dacia he does not mean ${ }^{32}$ the province of the Roman Empire, but is referring to the place which he identifies with Gepidae. ${ }^{33}$ And it is clear that Alpibis is equal to the Carpatians. Close to the left side of these mountains, in which the river Vistula is originates ${ }^{34}$ and which lose altitude towards the north, he places the populous Venethi tribe, who hold large areas. ${ }^{35}$ Except for this, he does not draw a holistic border for Venethi like he does in Gepidea but he states that they are commonly known as the Sclaveni and Antes ${ }^{36}$ and he gives a more detailed location for both of them.

Of the two tribes, he first discusses the Sclaveni and indicates that their land expands from the city of Noviodunum ${ }^{37}$ and the lake called Mursianus ${ }^{38}$ to Danaster $^{39}$ and to the river Vistula (Viscla) towards the north. He shares a few details by stating that in this place where the Sclaveni are located, there are cities, marshes, and forests. ${ }^{40}$ In his Sclaveni border depiction, he uses only 'north' as a direction and cuts this line with Vistula. Mentioned without any directions, Danaster is to the east of the Vistula so it must constitute the eastern border of the Sclaveni. The last element of this depiction, and at the same time the point where

${ }^{31}$ Iordanes Getica 34: Introrsus illis Dacia est, ad coronae speciem arduis Alpibus emunita.

32 Iordanes Getica 73: Daciam dico antiquam, quam nunc Gepidarum populi possidere noscuntur. Also Getica 74: Daciam appellavere maiores, quaenunc, ut diximus, Gepidia dicitur.

${ }^{33}$ Devillers 1995, p. 134, footnote. 55.

${ }^{34}$ In Getica 17 he stated that the Vistula originates in the Sarmatians mountains

${ }^{35}$ Iordanes Getica 34: iuxta quorum sinistrum latus, qui in aquilone vergit, ab ortu Vistulae fluminis per inmensa spatia Venetharum natio populosa consedit. For older records about Venedi / Venedae which are associated with Venet(h)i see Tacitus Annales 11. 23., Germania 46. 1. Tacitus hesitates whether to name them as Sarmatae or Germanae; Plinius Naturalis historiae IV 13. For a discussion of Curta about the relationship between Venedi which Tacitus and Plinius mentions and Venet(h)i cited by Iordanes, including its scientific development see Curta 1999, pp. 321-340.

${ }^{36}$ Iordanes Getica 34. [Venethi] quorum nomina licet nunc per varias familias et loca mutentur, principaliter tamen Sclaveni et Antes nominantur. Iordanes, referring to this passage, once more repeats this relationship among Venethi, Sclaveni and Antes. ab una stirpe exorti, tria nunc nomina ediderunt, id est Venethi, Antes, Sclaveni. Getica 119. For Iordanes' contemporary Procopius'explanation about Antes and Sclaveni's having the same name, but not Venethi, see

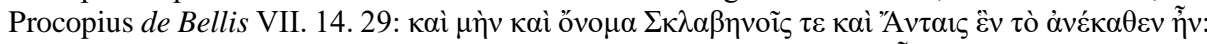

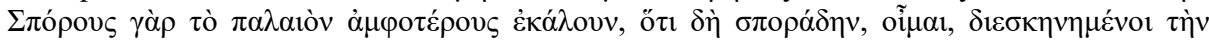

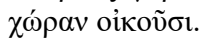

${ }^{37}$ Mommsen, also Novietunum; Moesia Inferior; modern Isaccea, Romania.

${ }^{38}$ Mommsen recorded the different forms in the manuscripts from the form of Mursianus (A) as Musiano (O) and Musianus (B). Mommsen 1882, p. 63.

${ }^{39}$ Dniester; Iordanes recorded this river which has two different names-Tyra and Danaster-with both its names in Getica 30.

${ }^{40}$ Iordanes Getica 35: Sclaveni a civitate Novietunense et laco qui appellatur Mursiano usque ad Danastrum et in boream Viscla tenus commorantur: hi paludes silvasque pro civitatibus habent. 
Iordanes starts to explain the location of the Sclaveni, is Noviodunum and Mursianus. In this case, the south and west directions remain for this duo that are mentioned together. Additionally, as there are multiple cities by the name of Noviodunum, localization may be possible by identifying the location of Mursianus. This controversial topic will be dealt with below, in the context of Scythia's southwest border.

Focusing on the Antes as his second point, he places its location between the rivers Danaster and Danaper. Stating that these rivers are separated by a distance requiring a few days' journey, he again goes into some details. What is interesting is that he defines the Antes as the bravest/the strongest fortissimo of all the communities living in the area where the Black Sea curves.$^{41}$ On this topic, which can be called as the human geography of Scythia in the $6^{\text {th }}$ century, he has up to now adopted a neutral perspective when mentioning the Gepidae, Venethi and Sclaveni, at least not describing them negatively or positively, but when he comes to the topic of the Antes there is a change in his attitude. Curta attributes this to the agreement $\ddot{\varepsilon} v \sigma \pi$ ov $\delta$ or the Antes signed with the Roman Empire. ${ }^{42}$ However, while it is a controversial topic, in the events of the second half of the $4^{\text {th }}$ century, two hundred years before this work was penned, 'the bravest' Antes (Anti) appears to be a community that was defeated by the Goths, who the Huns conquered previously. ${ }^{43} \mathrm{We}$ see the Antes in the eyes of Iordanes, a clearer expression that he approaches the Antes together with the Venethi and Sclaveni, in his evaluation which he compares his own time with that time while stating the previous period of these events between Antes (Anti) and Goths. In this record, he states that once these tribes, who formerly lived under the control of the Goth king Hermanaricus; now in Iordanes's time "are tyrannizing everywhere to punish our sins". ${ }^{44}$ This statement confirms the Slav raids from the Danube border

${ }^{41}$ Iordanes Getica 35: Antes vero, qui sunt eorum fortissimi, qua Ponticum mare curvatur, a Danastro extenduntur usque ad Danaprum, quae flumina multis mansionibus ab invicem absunt.

${ }^{42}$ Procopius de Bellis VII. 14. 33; Curta 1999, p. 326.

${ }^{43}$ Iordanes Getica 247. The tribe mentioned in this passage is recorded not as Antes-like the previous ones (Getica 35 and 119) but as Anti (In the passage it is in the form of 'Antorum' in genetive plural form; Mommsen also noted the forms atorum (A) and antarum (OB) found in the other manuscripts.) Curta (2001, p. 41) states that this dual use makes one think that he uses Latin in this passage and Greek sources in the previous two, like the one in Romana. We do not have any other information about where the tribe mentioned here is located. About the identicalness problem of the tribe mentioned in this passage with the one in the previous records (that is Getica 35 and 119) see Skrzhinskaia-2001, p. 326-327, endnote 610; About the study of the leader of the Goths, Vinitharius (who was responsible for the military expedition towards Antes (Anti))'s being historicized see Heather 2012, p. 172.

${ }^{44}$ Iordanes Getica 119: id est Venethi, Antes, Sclaveni; qui quamvis nunc, ita facientibus peccatis nostris, ubique deseviunt, tamen tunc omnes Hermanarici imperiis servierunt. 
which became relatively defenseless because of the west-focused political preferences during the period of Iustinianus. As for this study, Iordanes' term 'brave' for the Antes contradicts with the explanation of their relationship with the Empire. Nevertheless, all of them contribute to constructing the picture, in the eyes of Iordanes, of this tribe which he demonstrates as among the inhabitants of Scythia. When passing from the Antes' bravery to its geography, again we see a depiction which does not mention any directions. Yet, this time the case is clearer. The Antes lives in the area that stretches from Danaster, which he mentions while describing the location of the Sclaveni the west, to Danaper in the east. As he remarks that it is the bravest community not of Scythia but of the place where the Black Sea curves, the relationship of the south border with the sea emerges. However, the case about the northern borders remain a mystery.

He continues the depiction which he started with the Gepidae from the southwest of Scythia, from the south of the Carpathian Mountains, by heading the north of the Carpatians with Venethi (Venethae), towards the east with the Sclaveni and Antes until Dnieper. Among these tribes, the Gepidae, whose locations are depicted in detail, is a tribe with which Goths started their emigration in the direction of the Black Sea from Scandza. They leave Scandza with three ships together and it is then noticed that one of those ships has fallen behind. Stating that the Gepidae comes from the same origins as the Goths, Iordanes narrates that the reason for its separation from the Goths is their ship's falling behind and he expresses that some characteristics like 'thinking slowly and lumbering around', which are his own observations about the Gepidae, confirms this narrative. ${ }^{45}$ Devillers states that the three ships-definition is the symbolic expression of a community divided into three as the Ostrogoth, Visigoth and Gepid. ${ }^{46}$ Additionally, in this work of his where we witness that he compares the data his sources provide with his own observations, even if Iordanes states that Gepidae comes from the same origin as Visigoths and Ostrogoths, he gives less coverage to them in Getica than the other two Goth groups. With these details here about its location, he only distinguishes them from the Scythia tribes of his own age.

In the description of the Scythia of his age, Iordanes next moves from Danaper to the place where Vistula flows into the sea, from the Antes to the Vidivarii $^{47}$; namely, to the north west of Scythia. He does not use any definitions of direction for Vidivarii, either; he places them on the coasts of the ocean where

\footnotetext{
${ }^{45}$ Iordanes Getica $94-95$.

${ }^{46}$ Devillers 1995, p. 149, endnote 156. Also here Deviller states that this symbolism may have been used for the three-stage-Goth migration as Scandza - the Black sea - Roman Empire.

${ }^{47}$ It is claimed that the ancient name of East Prussia - Witland is associated with Vidivarii. Devillers 1995, p. 135, endnote 58.
} 
the Vistula's three mouths flow into it. Yet, when his definition of the Vistula as the west border of Scythia and his mention of the Vidivarii in a part of Scythia are brought together, the shores of the ocean he mentions must be in the east of Vistula. Also, as Vidivarii accommodates a lot of tribes under its domination ex diversis nationibus adgregati, these coasts starting from the east of the Vistula must have a capacity large enough to host these tribes. ${ }^{48}$ Furthermore, the Vidivarii also spread throughout an island on the Vistula which was abandoned by the Gepidae when they found more available lands for themselves. ${ }^{49} \mathrm{He}$ may have imagined a Venethi homeland spreading towards the south of the Vidivarii; (in other words, a Vidivarii homeland spreading towards the north of the Venethi), as the Vidivarii in the northwest of Scythia, being on the east of the Vistula river, lived on the coasts of the Baltic Sea in an area large enough to accommodate all of their tribes, the Venethi in the southwest of Scythia and the north Carpathians spreads throughout immense areas, the Venthi, Sclaveni, and Antes are listed from west to east, and there are no other tribes mentioned in this line. If that is the case, the expression "the immense space the Venethi covers per inmensa spatial" can now be accepted as explained because the west of Venethi is out of Scythia, Gepidae lies to the south of the Carpathian Mountains, and on the east there is Sclaveni; under these circumstances, the only possibility for the Venethi to have an immense homeland is for it to lie to the north direction.

After the Vidivarii he locates the Aesti "post quos ripam Oceani item Aesti tenent", again without using a direction, using a description made relative to the ocean. In that case, it is clear that the Aesti, which are beyond Vidivarii, are adjacent to and border the ocean. As the Vistula river delineates the border of Scythia and the Vidivarii are there, it is impossible for them to be to the west of them. As the Vidivarii hold the coast of the ocean like them, they cannot be to the south. That leaves only one possibility, that the Aesti are to the east of the Vidivarii. Thus, we see a Vidivarii-Aesti order from west to east at the northwest edge of Scythia. ${ }^{50} \mathrm{He}$ completes what he says about them, reflecting on Aesti's

${ }^{48}$ Iordanes Getica 36: Ad litus autem Oceani, ubi tribus faucibus fluenta Vistulae fluminis ebibuntur, Vidivarii resident, exdiversis nationibus adgregati

${ }^{49}$ Iordanes Getica 96: Hi ergo Gepidae tacti invidia, dum Spesis provincial commanerent in insulam Visclae amnis vadibus circumactam, quam patrio sermone dicebant Gepedoios. Nunc eam, ut fertur, insulam gens Vividaria incolit ipsis ad meliores terras meantibus. Qui Vividarii ex diversis nationibus ac si in unum asylum collecti sunt et gentem fecisse noscantur. In this passage Vidivarii was recorded as Vividarii and Vistula as Viscla. It is repeated that Vidivarii embodied different tribes exdiversis nationibus.

${ }^{50}$ Iordanes Getica 36: Mentioning Aesti, (recorded as Aestii) Tacitus places them again in a way that will be neighbor to the ocean, but to the east of Suevi. Tacitus Germania 45. 2. Similarly, Cassiodorus, in Theodoricus's letter to $(\mathrm{H})$ aesti which he also recalls Tacitus repeats that they are located at the coast of the ocean. Cassiodorus Variae 5. 2. 
being peaceful "pacatum hominum genus omnino." Unlike the Vidivarii, he uses the concept of direction in the depiction of the Aesti while stating that there is Acatziri ${ }^{51}$ to the south of them: "Quibus in austrum adsidet gens Acatzirorum fortissima." However, this distinction on the subject of Acatziri will far exceed merely specifying a direction.

Iordanes goes into particulars with the Acatziri which he did not previously in the Scythia 'section' of Getica. That is to say, he defines the Acatziri as a tribe who do not know farming and make their living by hunting and herding sheep: "frugum ignara, quae pecoribus et venationibus victitat." 52 This is the first time he includes a description of the occupations/lifestyle of the peoples he lists in this part. Moreover, he uses the adjective 'the bravest / the strongest' fortissimo that he used for the Antes, for the Acatziri as well; without making any geographic limitations. He states that farther beyond the Acatziri, ultra quos above the Black Sea supra mare Ponticum stretches the land of the Bulgars ${ }^{53} \cdot{ }^{54}$ Thus we come across a listing from north to south as one can start from the Baltic Sea with Aesti, continue with Acatziri to the south of them, and reach above the Black Sea with the Bulgars beyond them. ${ }^{55}$ On the other hand, as Dnieper is defined as the east

${ }^{51}$ Mommsen lists the different forms of this name which are in the manuscripts as follows: acatzirorum (HLAXYZ), acatzyrorum $(\mathrm{P})$, acatirorum $(\mathrm{V})$, agatzirorum $(\mathrm{OB})$. Mommsen 1882, p. 63 .

${ }^{52}$ Iordanes Getica 36. Apart from this section, a statement reminding the information which he gives about the Acatziri's lifestyle/way of living is also used for the Goth people. Iordanes stated that the places where these literate but poor Goths, who he states to be living in Moesia in his own time, is not suitable for farming, but he recorded they had pastures for herds of various species and forests for wood. Getica 267: Hodieque sunt in Moesia regionem incolentes Nicopolitanam ad pedes Emimonti gens multa, sed pauper et inbellis nihilque habundans nisi armenta diversi generis pecorum et pascua silvaque lignarum; parum tritici citerarumque specierum terras fecundas.

${ }^{53}$ Recorded in Getica 37 and Romana 388 as 'Bulgares', and in Romana 363 as 'Bulgari'. Mommsen lists the different versions of this name (the one in Getica 37) in the manuscripts: nulgarum (V), $\operatorname{burgarum}(\mathrm{O})$. Mommsen 1882, s. 63.

${ }^{54}$ Iordanes Getica37: Ultra quos distendunt supra mare Ponticum Bulgarum sedes. With reference to Maenchen-Helfen, H, Stürenberg, Relative Ortsbezeichnungen (Leipzig, 1932), 199 sqq, he states that the word ultra here means the 'east'. For example, as we can't locate Bosporus in the east of it relative to Maeotisas in the phrase ultraque Meotida per angustias Bosfori (Getica 30), rather it is located in the place where it meets the Black Sea-namely, located to its south, the possibility of Iordanes's using the word 'ultra' as standard can be eliminated. Maenchen-Helfen 1966, p. 279.

${ }^{55}$ For a different listing as a counter view see Maenchen-Helfen 1966, p. 278-280. There presents a quite different positioning by claiming that quibus refers not to the previous Aesti but the third previous, Antes. Iordanes defines as Antes as vero, qui sunt eorum fortissimi, qua Ponticum mare curvatur. In that case Antes must be in the curve of the Black Sea, it seems that this statement does not let one carry them to the north enough for another tribe to be situated between them and the sea. Furthermore, stating two activities, livestock and hunting for Altziagiri, when thought 
border of the Antes, Acatziri must be to the east of this river if the Bulgars and the undefined northern border of Antes overlaps with the south border of Acatziri. ${ }^{56}$

Regarding the events which happened nearly a hundred years before Iordanes wrote these lines, one can see the Acatziri ${ }^{57}$ in Priscus's narrative. Priscus stated that they lived along the Black Sea with other tribes. ${ }^{58}$ This narrative does not include any other elements that can help with their localization other than the Black Sea. Nevertheless, as Iordanes places the Acatziri between the Bulgars who live above the Black Sea and the Aesti who also hold the coast of the Baltic Sea, in Priscus's record of one hundred years earlier, it is understood that they are in the further south in the area surrounding the Black Sea. However, if the Acatziri, which Priscus defines as near the Black Sea in this era (in the mid $5^{\text {th }}$ century) is not at the same time in the place where Iordanes indicates, then Priscus provides data to clarify the question of why they should front the north, too. Namely, Priscus tells that in the era of Attila, the Huns struggled with the Acatziri, eliminating those who did not accept their rule and including the others in their dominion. If the elimination of those who resisted the Huns' rule has a meaning other than being massacred, it may mean a retreat towards the north from the coasts of the Black Sea. Furthermore, in his record dated from the years $462 / 463^{59}$, in the information he gives about the migration range of the Avar-

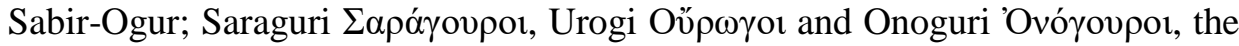

together with north-south ranking, seems in harmony with the steppe-forest belt in this geography. See Taaffe 2003, p. 43-47.

${ }^{56}$ Iordanes, while describing the area where the Antes dwelled as Dniester and Dnieper, stated that this place takes a journey that will last days quae flumina multis mansionibus ab invicem absunt (Getica 35) also in his description of Danaper (Getica 46) he stated that the river cum sit quadraginta dierum itinere navigabilis is suitable for transportation for the distance of a fourday journey, and this measurement is stated for only part of the river. Getica 35 the length of the distance between a Danastro ... ad Danaprum which he mentions will not be significant for a line or path parallel to the Black Sea. On the other hand, a type of fish living in this river which he gives for Danaper, and details such as its branch affecting the stream of it negatively makes one think that he knows this river very well. Therefore, in Getica 35 the possibility of his intending to state a distance between Danaper and Danaster, stretching vertically to the Black Sea arises. Independent of this possibility, in Iordanes's imagery, his record about the length of Danaper (Getica 46) leaves the impression that the places where the Antes live stretches towards the north, perhaps to the Acatziri, as he does not mention another tribe. See Kazanski 2013, p. 35 .

${ }^{57}$ For a comparative discussion of the forms of this name recorded in Priscus and the spelling in Iordanes see Maenchen-Helfen 1966p. 283-285. Even though Maenchen-Helfen stated that the correct form is Akatir, in this study Iordenes' spelling is followed as this study focuses on understanding Iordanes.

${ }^{58}$ Priscus Fragment XI/II line: 550. In this study Blockley (1983) edition is used for Priscus.

${ }^{59}$ e.g. Gordon 2013, p. 133. 


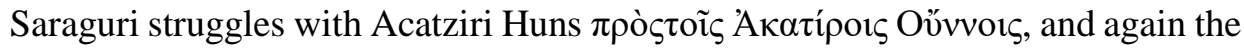
losing side turns out to be Acatziri. ${ }^{60}$ The Acatziri's characterization as Hun ${ }^{61}$ may refer to the group of them who were dependent on the Huns. Moreover, it is not the only grouping that can be done for Acatziri of this era. Priscus stated that there was a community of clans $\gamma \varepsilon \dot{\varepsilon}$ o $\varsigma$ and tribes $\varphi \tilde{v} \lambda \circ v$ who were led under

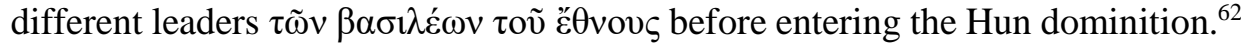

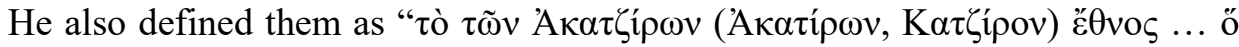
$\grave{\varepsilon} \sigma \tau \iota \Sigma \kappa v \theta \iota \kappa o ̀ v ~ \varepsilon ै \theta v o \varsigma=$ The Acatziri tribe is a Scythian tribe". ${ }^{63}$ There is no other information in Priscus about where this battle took place or where this Acatziri tribe lived. However, as it is tried to be disclosed here, the extraordinary characterization of Hun for may refer to the Acatziri community which was incorporated into the Hun dominion, that is still in the region surrounding the Black Sea. If that is the case, losing this battle may also have compelled the Acatziri to retreat to the North, probably for the second time, to the place where Iordanes indicated.

For Bulgars, Iordanes again uses the phrase "their being the punishments of our sins', as he did for the other peoples of Scythia, the Venethi, Sclaveni and Antes, this time 'notissimos' emphasizing: "quos notissimos peccatorum nostrorum mala fecerunt." ${ }^{64}$ As it is not possible for Bulgars to punish the Romans for their sins when located rather far from the borders of the Roman Empire, the need to seek a rationale for this description in their relations with the Romans indicates a place far from this region. In this context, it is seen that Bulgars, starting from the late $5^{\text {th }}$ century ${ }^{65}$ conducted raids targeting the Roman Empire. It is possible to observe that Iordanes includes these raids in his own narrative, not in Getica, but in the two records in his other work, Romana. In the first of these, he states that the Heruli, Gepidae and Bulgars often ravage

\footnotetext{
${ }^{60}$ Priscus Fragment XL/I

${ }^{61}$ The two works which we are informed about Priscus's record in our day are: Exc. de Leg. Gent. $14=$ Fragment XL/I and Suda A $18=$ Fragment XL/II it can be concluded that he recorded

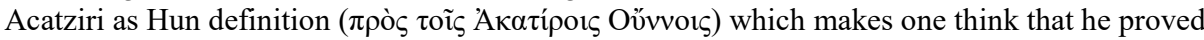
that the thing that is depicted here belongs to Priscus.

${ }^{62}$ Priscus Fragment XI/II. For an assessment about the social structure of Acatziri see Harmatta 1951, p. 137-138.

${ }^{63}$ Priscus Fragment XI/II line: 242.

${ }^{64}$ Iordanes Getica 37, defines Venethi, Sclaveni and Antes as facientibus peccatis nostris. Getica 119.

${ }^{65}$ Marcellinus Comes Chronicon a 499. For the assessment of an early record (Chronicon a. 493) in which he mentions the Scythian name not the Bulgar one for assessment of others see Çekil 2020 , p. 96 et. al.
} 
Illyricum. ${ }^{66}$ In his second record, which is the last passage of Romana and which deals with the period of time when it was written, he sets the incessant raids of the Bulgars, Antes, and Sclaveni just in the tragic context in which he presented those days of the empire. ${ }^{67}$ In that case, for the Bulgars to reach the Roman border from the point where he located them, at least for the second record, may be possible by crossing Antes and Sclaveni lands in their west. In the second record, namely in the middle of the $6^{\text {th }}$ century, these three communities are already mentioned together. Even so, it looks like a problem that the most familiar 'notissimos' one is not the Sclaveni nearest to the Roman border or the Antes to the east, but the easternmost Bulgars. This recognition can be explained to make an effect in its relations with the Roman Empire more than the other two horizontal synchronically or as vertical chronologically - as Pohl states - its being known long before relative to Antes and Sclaveni ${ }^{68}$ which are newly encountered in the contemporary works of Iordanes and Procopius or it could be related to both conditions. While the Bulgar narrative which Iordanes mentions only in this passage in Getica, and in his two records shown above in Romana does not allow one to reach a clear conclusion about his conception, but it may include both of them. That is to say, considering that the Bulgars had to cross Sclaveni and Antes lands to reach the Roman border, it must be inferred that they are more dominant than the others and the analogies between Chronicon and Romana should be added to the evaluation, too; as we can see in Marcellinus Comes they are the ones who targeted the Roman empire earlier than the others. ${ }^{69}$

\footnotetext{
${ }^{66}$ Iordanes Romana 363: Illyricumque saepe ab Herulis, Gipedisque et Bulgaris devastantibus, per suos iudices frequenter obstitit viriliterque cecidit. cf. Marcellinus Comes Chronicon a 530: Mundo Illyricianae utriusque militia ductor dudum Getis Illyricum discursantibus ...eos ...haut paucis eorum interemptis fugavit ... idem dux ... in Thraciam quoque advolans praedantes eam 'Bulgares felicior pugnans cecidit, quingentis eorum in proelio trucidatis. Mommsen 1882, p. 47 and footnote. 4.

${ }^{67}$ Iordanes Romana 388: Hi sunt casus Romanae rei publicae preter instantia cottidiana Bulgarum, Antium et Sclavinorum. Que si quis scire cupit, annales consulumque seriem revolvat sine fastidio repperietque dignam nostri temporis rem publicam tragydiae. cf. Procopius de Bellis VII. 14. 2. and Anecdota 18. Procopius does not mention Bulgars but he mentions Huns instead of them.

${ }^{68}$ Pohl 2018, p. 118. For the comparison of Procopius and Iordanes' data on Slavic people see Curta 1999; Curta 2001, p. 41 et. al.

${ }^{69}$ Even though Iordanes gives coverage to Antes-while describing the events arising after Hermanaricus in Getica 247-the case here is between Goths and Antes, and it is not related to the Roman Empire. In Getica 119, in the events of Hermanaricus Era; on the one hand while his mentioning Venethi, on the other hand in Getica 34 and -by referring to this passage-in 119 while stating that as well as naming ancient Venethi, in his own time Antes and Sclaveni are added to the same group of people; in his own age, his mentioning Antes just after Hermanaricus age probably means he refers to Venethi.
} 
On the other hand, in Getica, his work created to write the history of the Goths, he touches upon the Huns ${ }^{70}$ very often because of the historical intersection between Goths and Huns, so the probability of Iordanes's simply confusing them with another community, here with Bulgars, is the first to be eliminated. ${ }^{71}$ Actually Iordanes, as we witness in Marcellinus Comes, which we offered comparisons in the footnotes for these two records, in Procopius and in many other examples, does not mention the Huns by chance; on the contrary, he depicts them as one of the leading actors for the theme of his work. Hence, his probability of confusing those he presents as Bulgars here with Huns or in the next sentence his probability of identifying those he mentions as Huns with Bulgars can be eliminated. Yet in the $6^{\text {th }}$ century, defining the Bulgar people is itself a question for more than one study. ${ }^{72}$ Because of this, it is beyond the scope of this study. Within the scope of this study, namely in Iordanes's imagery, the Bulgars are a community who dwelled upon the northern Black Sea, (from there) capable of reaching the Danube border of the Roman Empire and taking military action in the Balkan lands of the empire, and as he clearly states, they are a familiar community. Including the information of Procopius that the Antes and

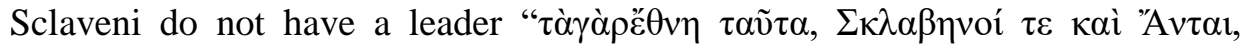

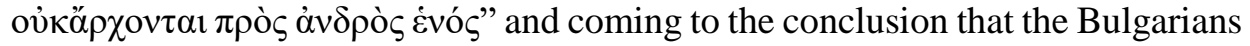
have a kind of dominance over these people may make his presentation of the Bulgarians as the most familiar and their crossing of Antes and Sclaveni lands more understandable. ${ }^{73}$

Huns take part in the following part of this narrative because of their relations with the two tribes in this area where the Bulgars dwelled: "Hinc iam Hunni quasi fortissimorum gentium fecundissimus cespes bifariam populorum rabiem pullularunt." ${ }^{\text {74 }}$ Iordanes depicts the situation in his era here because he

${ }^{70}$ In Getica, the name Hun is mentioned-except for pronouns and demonstratives-65 times, and the name Attila 49 times. For the parts where the name Hun is mentioned see Mommsen: 61/19, 63/10, 70/10, 89/6-16, 91/13-19, 92/ 1-3-6, 101/12, 103/13, 104/4-10-13, 105/6-10, 107/9-20, 108/20-24, 109/8-14, 110/9, 111/2-4-7-24, 112/10, 113/3-9-11-16-21, 114/20, 116/2-10, 121/15$18,122 / 1-4-8-18,123 / 8-13-15,124 / 12-13,125 / 22-24$ twice, 126/2-4-8-12 twice, 127/3-20, 128/ 21-26-27, 129/1. For an evaluation of the Hun narrative in Getica see Kaçar 2018, pp. 545-556.

${ }^{71}$ For the opposing view, e.g. Maenchen-Helfen 1973. p. 432; Skrzhinskaiâ-2001, p. 217-218, endnote 117.

${ }^{72}$ About these issues, primarily for a compilation of sources about Bulgars see Moravcsik 1943, p. 100-106; For a study which assesses the case in modern Bulgaria through archeological data between $6^{\text {th }}$ and 9th centuries see Doncheva-Petkova 2014, pp. 13-35; more widely for their presence in Balkans see Setton 1950, p. 502-543; for an evaluation about naming e.g. Pohl 2018, p. 27-28.

${ }^{73}$ Procopius de Bellis VII. 14. 22.

74 Iordanes Getica 37. Skrzhinskaia (2001, p. 67 and 218, endnote 118.) translates this sentence which she sees as one of the most difficult parts of the text as "А там и гунны, как 
uses present tense throughout this section; however, in this sentence about the Huns he uses perfect tense pullularunt ${ }^{75}$. Before this sentence, while talking about Bulgars and after the sentence telling who those communities are, he again used present tense. "Nam alii Altziagiri ${ }^{76}$, alii Saviri ${ }^{77}$ nun cupantur." Thus, "fortissimorum gentium fecundissimus cespes" we come across such questions as the timing of the two floods of the peoples that are created by the Huns, who are the most fertile sprouts of the bravest tribes, and we also come across the question of the interpretation of this statement. While there is no information apart from Iordanes's record here about Altziagiri, there is a lot of data about Saviri presented by different authors. ${ }^{78}$ Among them, as we see in the subject of Acatziri, there is Priscus's description about the movement of the Saragur, Ogur, and Onogur to Scythia because the Sabiri push them. ${ }^{79}$ In this record, the Saragur, Ogur, and Onogur appears to be the first generation to come to this region, and the Sabiri are the second one. The Saraguri from the first generation had relations

плодовитейшая поросль из всех самых сильных племен, закишели надвое разветвившейся свирепостью к народам"; Gindin (et. al. 1991, p. 109) “Там уже хунны, словно плодороднейший, дерн, [порождающий] могущественнейшие народы, разрастаются двумя свирепыми"; Devillers (1995, p. 16) “Ensuit, on trouve bientôt les Huns, souche pourraiton dire très féconde de nations très braves, qui ont fait doublement proliférer la rage de leurs peoples"; Mierow (1915, p. 60) "From this region the Huns, like a fruitful root of bravest races, sprouted into two hordes of people"; Maenchen-Helfen (1973, s. 431) "After these the Huns, like a cluster of mighty races, have spawned twofold frenzied peoples" they translated as seen above. While all the translations agree on the issue of the adjectives of Huns, namely their subjects and qualitative adjectives, they have differences such as dissociating about objects. In this study, the sentence following this one, was interpreted thinking that two peoples are mentioned. For the phrase 'two communities' see Cassiodorus Variae, 3, 6: pullulat ex uno genere quadrifariam decus. Mommsen 1882, p. 63, footnote. 2.

${ }^{75} \mathrm{He}$ uses the verb pullulare again in Getica 252, in the form of pululabat. For this usage, Mommsen states that it is synonyms with procreaverunt. Mommsen 1882, s. 196.

${ }^{76}$ Mommsen lists the forms of this ethnonym in the manuscripts as; altziagiri (HPVLAXY), altziagri (Z), --aulziagri (O), aulziagri (B), ultziagiri (PV), ultiziagiri (X), ultiziagri (Z), uultziagiri (L), autziagiri (A), aulgiagiri (O), aulziagri (B). Mommsen 1882, s. 63.

77 Mommsen showed the different forms in the manuscripts as; sauiri\}auiri (B), fauri (A). Mommsen 1882, p. 63.

${ }^{78}$ For a compilation of these records about Sabiri see Moravcsik 1943, p. 224-225. There is no sign of a relationship between the Altziagiri in East Scythia which we see here and Ultzinzures-the other forms in the manuscripts are ultzinzumes (X), ulzinzures (A), ulzingures $(\mathrm{O})$, ultzingures (B)-in West Scythia that is mentioned as one of the relatives Ultzindur consanguinei eius of Ellac in Getica 266 in Iordanes. However, Mommsen and Morevcsik focused on the relationship

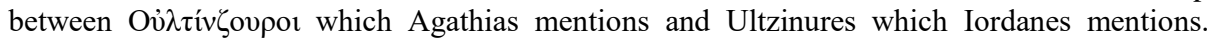
Agathias Historia 5. 11.; Mommsen 1882, p. 128 and 166; Moravcsik 1943, p. 198. To confirm the detection that no other record has been found see e.g. Skrzhinskaia 2001, p. 218-219, footnote. 119; Curta 2019, p. 35.

${ }^{79}$ Priscus Fragments XL/I and XL/II. 
with the Eastern Roman Empire in 462 / 463. In that way, we can reach data that can serve as the basis for when the migration of the first generation took place. Thus, the first generation must have entered the region before or at the latest on this date and the second generation, namely Sabiri, must have reached the region after this date. Even so, when taking into account that Getica was published in $551^{80}$, we see a long time span of 90 years. ${ }^{81}$ Eventually, it is understood that in at least one section of this period, namely after the years 462 / 463 and before the year 551, the Huns were in the lands where Bulgars lived during the period Getica was published.

Historicizing this statement is a more complicated process than the chronology of the clarification of events between Huns and Altziagiri and Sabiri. First comes the expression that Huns bifariam populorum rabiem brought out the two rages / two outbursts of peoples, then the question of who these peoples are -Altziagiri and Sabiri - and then the explanation that they all dwell in different places sedes habent divisas, and the depiction of these places follows it. ${ }^{82}$ This fiction of Iordanes creates the impression that after 462 / 463 the Huns removed the Altziagir and Sabiri from the lands where Bulgars lived, in 551 or pushed them in a different direction and they live in two different places now. If Iordanes really wants to let us know this, the Huns must have numbers and strength that can influence the fate of these tribes. In addition, while talking about this event in the east of Scythia, Iordanes describes the Huns more than that as "fortissimorum gentium fecundissimus cespes $=$ the most fertile sprouts of the most valiant tribes." The adjectives he uses to describe the Huns and the action they took seem to confirm each other. However, in the Danube line of the Huns which is close to the Roman Empire (the homeland of the authors of the sources), it can be thought that there is mismatch with the developments emerging after Attila's death. That is to say, with the events Iordanes presents, some of which are known only through his account, from the disagreements arising after the Attila era between his sons to the Gepidae uprising, to the war of Nedao and many defeats that occurred later, we witness that the Hun dominion almost evaporated in about twenty years. The general consensus among scientists is that

\footnotetext{
${ }^{80}$ For the discussion of when the writing of Getica was completed and whether the possibility of this year being 554, see Goffart 1988, pp. 98-100.

${ }^{81}$ Sabiri is found in Malalas's record about the beginning of the $6^{\text {th }}$ century in the age of Emperor Anastasius. Here, Malalas reports that Sabiri, passing the gates of Caspium, plundered the lands of the Empire. In terms of this study, this news helps us reach the conclusion that Sabiri has now been in Scythia at this date the latest. However, it does not contribute to the dating of Huns' influence on them and on the Altziagiri. Iohannes Malalas Chronographia XVI. 18. 70. (Jeffreys et al. 1986, 16.17. = p. 227).

${ }^{82}$ Iordanes Getica 37.
} 
advancement in the Danube line led to the collapse of the Hun kingdom as a whole. ${ }^{83}$ At the same time, towards the ends of these developments involving the west of Scythia too, it is added that the Saragur, Ogur, and Onogur migrations mentioned above reaches the east of Scythia. In that case, to the west of the Huns, in the era when the defeat of Huns and the collapse of their kingdom were observed, new peoples entering to the east of the kingdom and to the east of Scythia seems consistent with each other. However, in an era when the collapse of the kingdom the Hun kingdom is witnessed and even possibly after that, how can Huns elicit the outbursts of two tribes, at least one of which, namely Sabiri, is from the newcomers, and how can they direct these two peoples?

Iordanes mentions a migration to the east accompanying the defeat of Huns in the west. The first one of them takes place during the Nedao war in the 450s; Huns and their followers had thirty thousand losses including their supporters, and Ellac (Ilek). The brothers who survive, namely the sons of Attila, escape near the Pontus coast, which is the first place where Goths settled in Scythia: "Reliqui vero germani eius eo occiso fugantur iuxta litus Pontici maris, ubi prius Gothos sedisse descripsimus" ${ }^{84}$ Iordanes implies that the ones who head for the Black Sea are not just Ellac's brothers: Those who goes are Huns who are thought to take over the World "cesserunt itaque Hunni, quibus cedere putabatur universitas." While the Goths point out that the Huns occupied their old lands "Hunnorumque populum suis antiquis sedibus occupare" 85 , Iordanes clearly presents once more the migration of Hun people to the Black Sea. In all three records mentioning the Hun migration, the developments in the process that follow the Nedao war, which again Iordanes mentioned, are covered. Hence the migration took place after the war of Nedao after the year 454. On the other hand, the place where Huns settled, namely the old homeland of the Goths, may extend to the east of the sea of Azov. In addition to this, another battle of the post-Attila era takes place in the year 453/454 between the Goths and Huns in Pannonia, and the defeated Huns also reported going to Danaber, which they call 'Var' in their own language: "Danabri amnis fluenta praetermeant, quam lingua sua Hunni Var appellant". ${ }^{86}$ The fact that Iordanes mentions a fifteen-year Hun struggle;

${ }^{83}$ Vaczy 1982, p. 116-122; Thompson 2008, p. 191-200; Maenchen-Helfen 1973, p. 165-168; Heather 2012, p. 185-192.

${ }^{84}$ Iordanes Getica 259-263. Blockley gives the point which includes Attila's sons' migration to Scythia when they lost the war against their national subjects, by referring to Getica 259-263 and also referring to Mommsen; accepts that it originates from Priscus and presents it as Priscus's fragment XXV. Blockley 1983, p. 319-323, and p. 392, endnote 119; Mommsen 1882, p. XXXV.

${ }^{85}$ Iordanes Getica 264.

${ }^{86}$ Iordanes Getica 269. For an evaluation of this event from the history of the Goths see Heather 2012, p. 186-187. 
namely, the presence of Huns, what's more some of them taking refuge in the Roman Empire, shows that not all the Huns in the west of the Hun kingdom head for the Black Sea. Moreover, as we can see above, even though he states that the ones other than Ellac who were killed in Nedao escaped to the Black Sea, we witness the activities of Attila's sons, at least Hernac (Irnek) and Dintzicon (Dengizek) on the Danube line ${ }^{87}$ of the Hun kingdom. Thus, Huns either continued their struggles, the effects of which diminished gradually, or they moved to the Roman Empire just on the other side of the border. As one can see, both are regional solutions. However, the one relevant to this study, as we listed above, is their other activities apart from these two cases: their heading to the Black Sea, into Scythia. The development which is mentioned must have strengthened the Hun population, and thus increased the Huns' power. It can be thought that this process provided Huns with the power to influence the movements of people in Eastern Scythia, to influence the Altziagiri and Sabiri.

Returning to his time later in the text, while Iordanes does not mention the name Sabiri again, he offers a localization for the Altziagiri which is intertwined with their lifestyle; for, in order to graze their cattle "prout armentorum invitaverint pabula", the Altziagiri are on the steppes in the summer "quo Asiae bona avidus Mercator importat, qui aestate campos pervagant effuses sedes," near Chersonesus ${ }^{88}$ where the Asian wares come, and in winter they are above the Black Sea "hieme supra mare Ponticum se referents". ${ }^{89}$ While for the northern hemisphere, winter quarters are generally expected to be in the South and the summer pasture in the North, the summer pasture of Altziagiri is shown as the area surrounding Chersonesus which is in the south of the Crimean peninsula. Encountered again, the expression 'above the Black Sea' supra mare Ponticum this time is used for the winter quarters of Altziagiri which is possibly to the north of this place. Maenchen-Helfen, who thought that this place could be Sivash, drew attention to another point, stating that nomadic cattle herding with no mention of horses or sheeps, as Iordanes does here, is not common, as cattle should have a secondary role. ${ }^{90}$ From this perspective, the idea appears that Iordanes could not fully grasp the situation of the Altziagiri. And the fact that Procopius mentions the land which is used as grassland for the horses after the

\footnotetext{
${ }^{87}$ Iordanes Getica 259-273.

${ }^{88}$ Mommsen, also Cherson, Chersona. It is a Megara colony near Sevastopol, in the southwest of the Crimean Peninsula; it is one of the important centers of the Late Roman Empire in this region. Skrzhinskaia 2001, p. 197, endnote 92.

${ }^{89}$ Iordanes Getica 37.

${ }^{90}$ Maenchen-Helfen 1973, p. 171.
} 
Caspian Pass supports this idea. ${ }^{91}$ On the other hand, the fact that he mentions that the more distant Acatziri herd sheep while the Altziagiri he indicates as close to Chersonesus herd cattle may show that he conducted thorough enough research to distinguish different species of livestock. If that is the case, a refined historian and a depiction appears before us.

As the last topic of this section, we see the trade elements which he mentions while referring to economic actions (which we came across) in the description of the Altziagiri and trade that we see in the depiction of Chersonesus together in the sample of Hunugiri ${ }^{92}$ in which we see trade and economic actions in one body in a detailed way ${ }^{93}$. He states that it is now a known fact that the Hunuguri trade marten pelts. ${ }^{94}$ Having already mentioned the commercial aspects of seven cities including Chersonesus, he widens his depiction by adding the goods coming from Asia to the commercial features of Chersonesus. However, the Altziagiri are not mentioned with any qualifications other than being the neighbors of this city; they are not mentioned in connection with a commercial activity. Putting aside these cities whose Greek identities are indicated, the only Scythian tribe which he mentions as having commercial activities is the Hunugiri. ${ }^{95}$ Another factor that distinguishes them in the depiction of Scythia at least considering that the Sabiri are mentioned to dwell in a separate location from the Altziagiri - is that they are the only tribe without information about their locations. In this section, if the west-east direction seen in Iordanes's VenethiSclaveni- Antes and Vidivarii- Aesti descriptions reflects his inclination, as the Hunugiri are mentioned at the end, they should be in the easternmost part. Starting

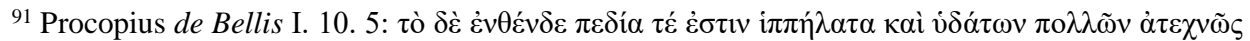

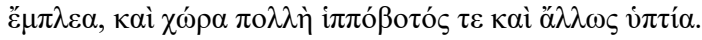

${ }^{92}$ Mommsen lists the different forms in the narratives as hunuguri (HVLAXZ) hunugguri (P), uniguri (L), hunucari (OB) hunugiri (Y). Mommsen 1882, p. 63. Maenchen-Helfen on 1973, p. 438 states that this name is the same as Onoguri. For a compilation of sources about Onoguri (Ovóyoupot) see Moravcsik 1943, s. 189.

93 The opposing view: Maenchen-Helfen, by stating that the flow of narration creates the expectation of continuing with Sabiri, concludes that for Iordanes, the Sabiri and Hunuguri are the same people. Maenchen-Helfen 1966, p. 279. As stated above, I consider that there is no problem in the text flow when lifestyle / economics and business continuity is taken into account. In addition, I believe that this possibility is not strong for Iordanes, who on the one hand relied heavily on Priscus, and on the other hand recorded many tribes which we can know about only thanks to him.

${ }^{94}$ Iordanes Getica 37: Hunuguri autem hinc sunt noti, quia ab ipsis pallium murinarum venit commercium.

${ }^{95}$ On the topic of Aesti, if he benefits from Tacitus or Cassiodorus, it turns out that he does not find it necessary to use the information that both of these authors provide about this tribe's trading amber; however, a few sentences later he talks about marten pelt trade here. Tacitus Germania 45. 5-7; Cassiodorus Variae V. 2. 
from this approach, in the south of Bulgars who are above the Black Sea, in the Crimean Peninsula there is the Altziagiri, on the east of them Sabiri and Hunugiri is located. In this way, Iordanes completes the section which he devoted to the depiction of Scythia. However, a piece of information he gives about Huns while he was explaining the location of Scythia is related to this place, East Scythia.

Iordanes talks about the Huns while he is describing the east, and if I narrow the area further, the southeastern border of Scythia. ${ }^{96}$ As we saw above, he addresses not the past actions and locations of the Huns, as he uses present tense, but he focuses on their situation in his own age. That is to say, he talks about the Huns who were there at the time when his literary work was written. We come across the Huns, the discussion of whose location is given below, north of the Caucasian mountains. Another group of people is not mentioned in East Scythia except for the Altziagiri, Sabiri and Hunugiri, which he lists after Bulgars at the end of Scythia section, and except for the Huns who he mentioned at the beginning of this section. We found the traces of Huns who were reported to have migrated to the Black Sea in the other passages of Getica in the third quarter of the $5^{\text {th }}$ century, probably after this date, as stated in the Scythia section, in the areas above the Black Sea where from then on Bulgars dwelled. However, as I discussed above, this trace belonged to the past, and in the mid $6^{\text {th }}$ century, Bulgars were seen in this region. And after that, Iordanes states that in the mid $6^{\text {th }}$ century, if they probably were not here earlier, they were in a more eastern location, in the north of Caucasians, (too). Thus, on the one hand, the Huns fall into the catalogo gentium of Scythia; while on the other hand, his positioning the Huns north of the Caucasians supports my opinion that when the Huns are concerned, the possibility that he confused or identified them with another people is not valid, because his presenting the Huns in the same geographic locale (east Scythia) and time period (mid 6th century), with the name Huns applied to north of Caucasia (Getica 30) while the name Bulgars used for peoples above the Black Sea (Getica 37) cannot be explained otherwise.

Iordanes also provides data on the depiction of the human geography of Scythia before his own time. A few samples will be provided among these depictions here as they demonstrate his identity as a historical geographer. These records go down to the Amazons, which Herodotus mentions. Iordanes states ${ }^{97}$ that their origins date back to Scythia. ${ }^{98}$ In addition, he reflected that Scythia was once, he used perfect tense permiserunt, the home of wild tribes who allowed

\footnotetext{
${ }^{96}$ Iordanes Getica 30: ... in sinistram partem reflexa post mare Caspium ... vergens ad Hunnus, Albanos et Seres usque digreditur.

${ }^{97}$ For an analysis of the Amazon narrative in Getica 56 and 57 on Amazons, warrior women, -the analysis is related to the narrative in Herodotus-see Hartog 1997, pp. 211-218.

${ }^{98}$ Iordanes Getica 52: Scythiae genitae feminae
} 
Greeks to establish cities: "indomiti Scytharum nationes Grecis permiserunt condere." He mentions the seven cities, which he defines as not unimportant oppidis haut obscuris, among which are Chersonesus and Olbia ${ }^{99}$, giving the impression that they are ordered from west to east and bringing these cities to his own age. ${ }^{100}$ In other words, these cities established by the Greeks are still standing in the mid $6^{\text {th }}$ century. The Amazons seem to enter in this composition thanks to the Goths, whom they presented as their husbands rather than themselves. Their existence seems to indicate that even in ancient times, "indomiti Scytharum nations" the wild tribes of Scythia were not the only reality of Scythia.

He records that the Goths meet the Spali after arriving in Scythia and do battle with them, thus reaching the far shores of the Black Sea. ${ }^{101}$ In this record of Iordanes while it is not clear which part in the vast and extensive Scythia the Goths choose to be their homeland, but he later defines this event ${ }^{102}$, by which it is possible for them to reach the further coast of the Black Sea by defeating the Spali, as the first migration of Goths to Scythia and states that this place is near the marsh of Maeotis: "Quorum mansione prima in Scythiae solo iuxta paludem Meotidem". He explains that from there, the Goths pass to Dacia, Moesia, and Thracia, and that the Goths, who are already more knowledgeable than all Barbarians settled above the Black Sea, were wise people in the third phase of

\footnotetext{
${ }^{99}$ A colony established by the Milesians, it is placed at the mouth of the river Borysthenis.

${ }^{100}$ Iordanes Getica 32. The listing is as follows: Boristhenis, Olbia, Callipolis, Chersonesus, Theodosia, Careon, Myrmecion ve Trapezus. Altough Iordanes pointed the first two of these cities-Borysthenis and Olbia-as two different cities, actually Strabon (VII. 306) and Ptolemaeus (Geographia III. 5. 14.) are two different names used for the same place. Skrzhinskaia states the possibility of Iordanes presenting it as two cities because of the fact that Iordanes benefited from Pomponius Mela (de Chorographia II. 6.) Mierow 1915, p.148, Skrzhinskaia 2001, p. 196, endnote 89. However the issues about these cities are not limited to this confusion. There are various problems, from whether the cities actually exist to their location. For details see Skrzhinskaiā 2001, p. 196-199, endnote 90-91 and 93-96.

${ }^{101}$ Iordanes Getica 28: ad extremam Scythiae partem, que Ponto mari vicina est cf. Plinius Naturalis Historia VI. 7. In this passage, Plinius recalls two tribes that looks like Spali while talking about the tribes which are in the basins of the two rivers: Spaei which is in the surrounding area of Ocharius (a river pouring into Maeotis) and Spalei which is in the place surrounding Tanais.

${ }^{102}$ Mentioning Plinius Mierow, while pointing out that it can be a group people living in the place surrounding Don, he states that one should expect that Venethi, not Spalaei, should be in this record. Devillers, mentioning Plinius again, relates Spali to 'Satharcei Spalei' a tribe living in Scythia, specifically in caves in Caucasia. Two different suggestions arise in the sample which is chosen, but in the Plinius record, while listing a group of tribes, Iordanes mentions only one tribe, Spali. If Iordanes cites from Plinius in this passage, I think the fundamental issue lies in the explanation of why Spali is chosen among this dozen of tribes. Plinius Naturalis Historia 6. 7. 22, Mierow 1915, p. 147, Devillers 1995, p. 132, endnote 43.
} 
their migration and in the second phase of their migration to Scythia. ${ }^{103}$ Devillers defines these three phases, with the first being the history or legends of the Scythians, the second being the history of 'geto-dacia', and only the third being the history of original Goths since the 3rd century A.D ${ }^{104}$ Heather evaluated the narrative of Gethica compared to archeological data and stated that changes which were intensified in the $3^{\text {rd }}$ century in the Polish-Ukrenian line were observed. ${ }^{105}$ The narrative that Iordanes set around the first two phases of Goth migration, which he presented as three-phased, provides an example of his being anxious to build a history that goes deeper into the past as well as stressing that the Goths are wise people. If this formation belongs to Ablabius and/or Cassiodorus and if Iordanes embellished his work with quotes from some other authors like Pompeius Trogus, then this time it sets an example of his concern with compiling a Goth history which is "rooted" in the past. ${ }^{106}$ Whatever possibility applies, the fact that Scythia is the place selected for the series of events in the first and third migrations remains constant -that does not change.

Where is Scythia?

The Scythia narrative, which looks like a subsection of the geography section of Getica, offers a general framework for the question of where Scythia lies in Iordanes's conception. He starts the Scythia section by presenting its borders, just like he does in the two models, Britannia ${ }^{107}$ and Scandza ${ }^{108}$, which he previously covered. However, although he mentions and quotes other authors, in the previous sections, he doesn't mention any authors here, which distinguishes this section from the others. Only before starting this narrative, he states that Iosephus gives incorrect information by stating that Goths are of Scythian origin. ${ }^{109} \mathrm{He}$ explains his rationale in writing the Scythia section as seeing the necessity of "providing information about the borders of this place just as it is

103 ...omnibus barbaris Gothi sapientiores semper extiterunt... Tertia vero sede super mare Ponticum... Iordanes Getica 38-40 and 42.

104 Devillers 1995, p. 135-136, endnote 66.

105 Heather 2012, p. 63 et al.

106 "Of course, if anyone says that the Goths exist as different people than we describe in our city, they will contradict us because on our behalf, we prefer to believe what we read rather than relying on the stories of old women." "Aut certe si quis eos aliter dixerit in nostro urbe, quam quod nos diximus, fuisse exortos, nobis aliquid obstrepebit: nos enim potius lectioni credimus quam fabulis anilibus consentimus." Getica 38. It is thought that the statement above, which follows the narrative belonging to the migration to Moesia, Trachia, Dacia in just the second phase of the Goth migration, is made to defend his narrative belonging to these two phases. He already covers the narrative of the first phase in just the following part, starting from Getica 40.

${ }^{107}$ Iordanes Getica 10-15.

108 Iordanes Getica 9 and 16-25.

${ }^{109}$ Iordanes Getica 29: ... Scythas eos et natione et vocabulo asserit appellatos. 
located, before moving to our main topic." 110 Iordanes presents the location of Scythia in two successive passages, overlapping significantly, in two different versions. The first version: "Now the border of Scythia stretches to the place where the river Ister ${ }^{111}$ originates and where the Morsianus marsh ${ }^{112}$ swelled in Germania; to the Tyra ${ }^{113}$, Danaster and Vagosola ${ }^{114}$ rivers and also to the great Danaper and to the Scythia Taurus ${ }^{115}$ mountain, which meets Maeotis from all sides, the one not in Asia but in our place here; and towards the back of Maeotis, and after the Bosphorus ${ }^{116}$ strait to the Caucasus mountains, and to the Araxes river. [Scythia] On the left side, with its mushroom-like shape which first narrows and then expands ${ }^{117}$, turning back from the Caspium Sea (which is) part of the northeast ocean in the furthest part of Asia, and then stretching to Huns ${ }^{118}$, Albania ${ }^{119}$ and Seres $^{120}$ it is abandoned." ${ }^{121}$ The second version: "I say this

${ }^{110}$ Iordanes Getica 29: Cuius soli terminos, antequam aliud ad medium deducamus, necesse est, ut iacent, edicere.

${ }^{111}$ When used as (H)Ister like the one here, it is the east / down channel of the river Danube; In the Mommsen edition this name-except for the form of Danubis / Danuvius, which was used many times-is also recorded as follows: Hister Bessorum lingua (75) 75/16, Hister (54) 68/18, (114) 87/17, Ister (30) 61/12, (32) 62/3, (33) 62/12, (H)ister qui et Danubius (32) 62/3, (114) 87/17.

112 Also recorded as Mursianus lacus in the Mommsen edition (35) 63/1.

113 The Greek name for the river Dniester. Here he recorded the same river using both of its names, Tyra and Danaster. Mierow 1915, p.147.

${ }^{114}$ It is seen once in the text. It is understood to be Hypanis-South Bug in European Sarmatia by the ordering of the rivers Mierow 1915, s.147.

${ }^{115}$ A mountain stretching from southwest to northeast in the Crimean Peninsula.

${ }^{116}$ Kerch Strait, which connects the Sea of Azov to the Black Sea. This strait is usually seen as "Bosporus Cimmerius" in Latin sources.

${ }^{117}$ See Cassiodorus Variae 3. 48: graciliora sunt quant cacumina et in mollissimi fungi modo superius extenditur, cum inferiore parte tenuetur.

${ }^{118}$ In the Mommsen edition it is recorded as Hunnus (HP) here, also the alternative forms in the other manuscripts are recorded as; Hunnis (V), Hunnos (LBX), Unnos (O), Hunos (AY). Mommsen 1882, p. 61.

${ }^{119}$ Albanos, the North of river Kura in Caucasia. TransCaucasia - Shirvan/Şirvan; a community formed by different tribes in the east of Caucasia. Devillers 1995, p. 134, endnote 50.

${ }^{120}$ The name Seres, also in Latin Serae, $\Sigma \tilde{\eta} \rho \varepsilon \varsigma$ comes from the word "serica" in latin and " $\sigma \eta \rho \iota \kappa \alpha$ " in Ancient Greek meaning "silk". Over time, this word started to be used in relation to the people trading silk. The Latin and Greek authors used this name for the Sogdiana people of central Asia. Seres was also used in order to name China. For details see Brill's New Pauly, 'Seres'. http://dx.doi.org/10.1163/1574-9347_bnp_e1109630 (January 2020).

${ }^{121}$ Iordanes Getica 30: Scythia si quidem Germaniae terre confines eo tenus, ubi Ister oritur amnis vel stagnus dilatatur Morsianus, tendens usque ad flumina Tyram, Danastrum et Vagosolam, magnumque illu Danaprum Taurumque montem, non illum Asiae, sed proprium, id est Scythicum, per omnem Meotidis aditum, ultraque Meotida per angustias Bosfori usque ad Caucasum montem amnemque Araxem ac deinde in sinistram partem reflexa post mare Caspium, quae in extremis Asiae finibus ab Oceano eoroboro in modum fungi primum tenuis, post haec latissima et rotunda forma exoritur, vergens ad Hunnus, Albanos et Seres usque digreditur. 
country, namely Scythia, extends to its length and spans its width; it has the Seres in the east who have lived on the shore of the Caspium Sea since the beginning, the Germans and Vistula river in the west, surrounded to the north by the ocean, with the Persida, ${ }^{122}$ Albania, Hiberia, ${ }^{123}$ Pontus $^{124}$ and the farthest channel of the Ister, which is named the Danubius from the source to mouth, in its south." $" 125$

Based on the relationship between the Caspium Sea being likened to a mushroom in the first passage, and Cassiodorus' likening a city surrounded by mountains to a mushroom, Merrills states that this passage (Getica 30) was likely taken directly from Cassiodorus's lost Goth History. ${ }^{126}$ Even if coming across this simile in Getica, which is actually in Variae, takes us to the possibility of quoting from Goth History, it seems that whether the source of most of the passage which is not in Variae is Iordanes or Cassiodorus is doomed to remain unknown. Even so, whether he wrote it himself or he quoted it or it is part of a summary study, at least as he preferred to use this narrative in his own work, the effect of Iordanes on this text is obvious. While Iordanes in the first of these two passages/versions (Getica 30 and 31) included places inside and outside Scythia's borders, in the second one he mentions only those outside of them. In the first he states an order that goes from west to east without mentioning the directions, whereas in the second he indicates directions, preferring a depiction in order from east, west, north, to south. As will be discussed below, in the other passages of Getica with non-holistic depictions as in these two passages, Iordanes gives information which sometimes provides insight into his conceptualization of where Scythia lies, and sometimes gives additional information that obscures understanding.

In the first passage, he starts to describe the borders of Scythia by explaining the border shared with Germania; in this border he mentions two places, both of which have their own problems: stagnus Morsianus and Ister. The problem with Mursianus lies in the difficulties of its location, the expression Ister

\footnotetext{
${ }^{122}$ It seems to be used instead of its common form Persia. A country between Carmania, Media and Susiana. Mierow 1915, p.148. In Mommsen edition this name is recorded as follows: Mommsen: Persae (61) 71/5. (63) 72/1. (110) 86/16. Persis (Persida) 62/2.

${ }^{123}$ Or Iberia; approximately the modern Georgia.

124 The Black Sea; In Mommsen edition this name is recorded as follows: Mommsen: Pontus regnum (31) 62/2, Pontus mare (28) 61/3, (46) 66/2, (54) 68/17, (63) 71/16, (75) 75/14, (82) 78/5, (89) 80/14, (91) 81/16, Ponticus (32) 62/4. Ponticum mare (35) 63/3, (37) 63/9, (37) 63/14, (38) 63/17, (42) 64/21, (263) 126/1.

${ }^{125}$ Iordanes Getica 31: Haec, inquam, patria, id est Scythia, longe se tendens lateque aperiens, habet ab oriente Seres, in ipso sui principio litus Caspii maris commanentes; ab occidente Germanos et flumen Vistulae; ab arctu, id est septentrionali, circumdatur oceano, a meridiae Persida, AIbania, Hiberia, Ponto atque extremo alveo Istri, qui dicitur Danubius ab ostea sua usque ad fontem.

${ }^{126}$ Merrills 2005, p. 158.
} 
oritur amnis which says that the Ister river originates also, fuels these difficulties. Taking the source of the Ister and Mursianus into central Europe ${ }^{127}$ to create the border between Scythia and Germania is inconsistent with information about Sclaveni ${ }^{128}$ and Gepidae ${ }^{129}$ in a passage of Getica that will be discussed below. The problem may arises from the verb oritur in this expression being recorded incorrectly, and if one accepts the view that this verb should be orditur ${ }^{130}$ is accepted, the part of the problem concerning the Sclaveni can be overcome. ${ }^{131}$ Thus, the place to look for Morsianus should be the mouth and not the source of the Ister, in other words, it should be at its connection to the sea. When considered together with the other passages of Iordanes related to this topic, in spite of this dispute, it seems more appropriate to place Mursianus in the north-west Romania - surrounding South Moldova - around Galati and Isaccea.$^{132}$ Of course, when this approach is accepted, another discrepancy arises because of that Ister in Getica 30 and Mursianus are depicted together with Germania.

Even if Ister, in this context, is situated as the region where it flows into the Black Sea, Scythia extends to the river Tissa flowing along Serbia - Hungary. Tisza constitutes the northwest border of Gepidae ${ }^{133}$ which is in the west of Scythia, so forming the southwest border of Scythia. While presenting the southwest border of Gepidae together with Tisza in this composition he mentions Danubius, not Ister. But we see the Ister as the place where the river Flutausis (Aluta) flows in central Romania, which constitutes the east of Gepidae. In this

\footnotetext{
127 e.g. in Mierow 1915, on p. 147. a marsh in the surroundings of Musra in Pannonia was named as modern Ezsek.

${ }^{128}$ Iordanes Getica 35. While the location of Sclaveni is being given here, laco qui appellatur Mursiano his using the phrase-the lake called Mursianus-when compared to Morsianus stagnus (different forms in the manuscripts; Morsianus HPVLXZ, Mursianus Y, Musianum B, Morsiamon A) which he mentioned in Getica 30- makes one think that he may have talked about two different places. Because firstly, he defines the place which he mentions as stagnus, but a few sentences later, he defines it as lacus; furthermore, he expresses how this place is named. His focusing on how a place is named a few sentences after mentioning it is not suitable for the flow of narrative, either. Also, as we witness in the sample of Maeotis, his always defining this place as palus shows that he can reach a standard in such definitions. This raises the probability that Morsianus stagnus and Mursianus lacus are different places. Mommsen 1882, p. 61, 62; Gindin et. al. 1991, p. 122, endnote 59 and p. 134, endnote 106.

${ }^{129}$ Iordanes Getica 33.

${ }^{130}$ From Hauptmann, L., "Les Rapports des Byzantins avec les Slaves et les Avares pendant la seconde moitié du VIe siècle", Byzantion 4, pp. 137-170, p. 138, footnote 2 transferred Madgearu 1997, s. 88.

${ }^{131}$ For the opposing view against this suggested solution offer which is based on text repair see Skrzhinskaiā 2001, p. 191-193 endnote 76. Skrzhinskaiā, not accepting Iordanes's making such a mess (confusion) at all, objects it. However, this confusion may have resulted from copyists.

${ }^{132}$ Madgearu 1997, p. 88 and 89.

${ }^{133}$ Iordanes Getica 33.
} 
context, it is understood that the Ister, in the eyes of Iordanes, stretches at least into the central Romania, but does not reach the conjunction of the Danube and Tisza rivers.

While describing the southern border in the second version of Scythia's location, his use of the expression; "Istri, qui dicitur Danubius ab ostea sua usque ad fontem" meaning "the Ister which is named Danibus from the source to the mouth" clarifies the situation in one way, and increases its complexity in another. That is to say, on the one hand he gives the impression of discriminating between the Danubius and Ister and embraces the idea of Ister's being used to name the east of the Danube. On the other hand, however, he extends the Ister, which he mentions as extremeo alveo Istri, westward to completion of the south border of Scythia, namely to the west of Gepidae. As a result, the problem of consistency in Getica in determining the location of Scythia on this border cannot be overcome completely. Among these consistency problems in the first version, between Ister and Mursianus which are pointed as Germania and Scythia border, at least the information of Ister's constituting not this border but the border of Scythia with Roman Empire is included. Finally, despite the inconsistencies, if based on the definition in Getica 33, due to more refined quality, it is understood that the area where the Gepidae people spread, namely Tisia and Danubius, constituted the south of the Germania-Scythia border, which is the southwest border of Scythia. Bordersen's detection ${ }^{134}$ that geographical depiction in the Greek Roman world primarily depends on the texts instead of the map, may explain these issues that are considered inconsistencies in Iordanes's work. If he had made separate checks for the places he included in his works on the map, especially while giving information about their locations, he would probably have resolved these confusions.

Before this section Iordanes, while describing the location of Scandzia, also made a definition over the Vistula River, stating in this context that the Vistula that it formed the border between Germania and Scythia: this island (Scandza) is opposite the Vistula river Vistulae fluminis which is born from the mountains of Sarmatians dividing Scythia and Germania. ${ }^{135}$ In the second passage devoted to the location of Scythia, Iordanes described its direction clearly, stating that the Vistula river is to the west of Scythia together with Germans: Scythia .... ab occidente Germanos et flumen Vistulae ${ }^{136}$.

\footnotetext{
${ }^{134}$ Brodersen 2012, pp. 109-110.

${ }^{135}$ Iordanes Getica 17: a fronte posita est Vistulae fluminis, qui Sarmaticis montibus ortus... Germaniam Scythiamque disterminans...

${ }^{136}$ Iordanes Getica 31.
} 
Therefore, in Iordanes's perception of space, a need arises to evaluate the Vistula river and the mountains of Sarmatians together with Tisia, Danubius, Mursianus and Ister, and on the other side together with Germania/Germans forms the west border of Scythia. Based on this, the Vistula originates in the mountains of Sarmatians and empties into the ocean, forming a border between Scythia and Germania, and on its west and southwest are the Tsia, Danubius, Mursianus and Ister. According to our current geographic knowledge, the Scythia's western border, in the east-west direction, follows the Danube from its mouth to Serbia, unites with the river Tisza, fronting the Carpatian mountains in the south-north direction over Hungary, and later it reaches the Baltic Sea following the Vistula river. Briefly, it can be traced as the Black Sea- DanubeTisza- Carpatians- Vistula- Baltic Sea.

There are also problems in understanding the south and southeast borders of Scythia. In these depictions, there are two places directly mentioned and one indirectly mentioned as geographical elements. "[Scythia $]$ tendens .. ad Caucasum montem amnemque Araxem", when it is thought that Caucasus which Iordanes mentions firstly, stretches to India from Russia as previously mentioned, it will not be of much help in order to determine the border. About Araxes, which is the second one in this ranking, even if Iordanes does not make a clear localization, he stated that it originates in the Caucasus and flows into the Caspian Sea. ${ }^{137}$ In the depiction of the borders of Scythia, the place which is mentioned not on its own but mentioned indirectly because of its relationship with the element used in this depiction is the Caspium Sea, which is mentioned in both versions. In the first version he says that "when turning back from this sea, on the left, there lies the Huns, Albania, and Seres, after which Scythia is abandoned" "vergens ad Hunnus, Albanos et Seres usque digreditur"; in the second version: it is mentioned while it is being stated that $a b$ oriente Seres in the east of the Scythia live on the coast of this sea. Except for them, he used tribe and place names in both versions. In the first version, the ones in the last part, namely in the easternmost part of a depiction which goes from west to east as Huns, Albania and Seres are given in an order. In the second version, as the depiction is done over the ones outside of Scythia, the Huns are not mentioned; Albania and Seres who are listed after them are mentioned. However, this time Albania and Seres are not given successively, Seres is stated as in the east of Scythia, and Albania is indicated as being in the south, between Persia and Hiberia "a meridiae Persida, AIbania, Hiberia". The southern line (border) in the second version goes

\footnotetext{
${ }^{137}$ Iordanes Getica 54. It is commonly identified with the Aras which flows into the Caspian, forming the border between Azerbaijan and Iran. http://www.iranicaonline.org/articles/araxesriver\#prettyPhoto (W. B. Fisher, C. E. Bosworth: Volume II. Fasc. 3, pp. 268-271).
} 
from east to west, so we encounter the order as follows: Persia, Albania, Hiberia, Pontus, and Ister. As Persia, Albania and Hiberia come before the Black Sea in this ranking, it is clear that all three are to the southeast of Scythia.

When both depictions are combined, an approximate delineation of the southeast border of Scythia arises as the Black Sea, Hibariea, Albania, and finally the Persia. Iordanes may have stated one more thing to make it easier for us to understand this border. That is to say, the 'left side' sinistrum latus in his expression the left side of Alpes (Carpathia), which he will state after a few sentences refers to the north. ${ }^{138}$ When considered together with this expression, 'in the left side' in sinistram partem in the first version must be indicating the north in the phrase 'after returning from the Caspium Sea' reflexa post mare Caspium. In that case, if Iordanes made a 'left side' definition on a map, he gives the impression that he is examining the map with the west side facing himself. The Caspium Sea enters the depiction after the Araxes, which empties here. Because of that, the 'left side' expression must be indicating the north of Araxes. This situation is also consistent with Albania and the Huns being located to the north of Araxes. ${ }^{139}$ If we show their position with each other based on the ranking of Iordanes, the Huns whom he mentions first are to the north of Albania. Therefore, it emerges that Huns, Albania, and Seres order must be localized from the north to the south. Since this border is shown as Hiberia- Albania- Persia in the second passage, in that case the most suitable, and even the only alternative is seen as the north of Caucasians.

In the two passages where he presented the location of Scythia, it was mentioned that there may be inconsistencies between the information he gives about the southwest border of Scythia and the information he provides in the following passages, there are also elements that can lead to a conclusion of inconsistency regarding the southeast border, which he describes in less detail. This is due to the fact that Iordanes locates first Albania and Seres with Huns,

${ }^{138}$ Iordanes Getica 34: Alpibus ..., iuxta quorum sinistrum latus, qui in aquilone vergit, ab ortu Vistulae fluminis per inmensa spatia Venetharum natio populosa consedit.

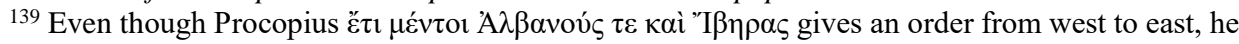

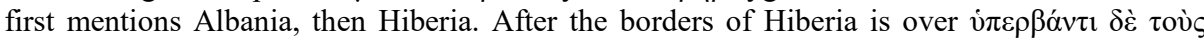

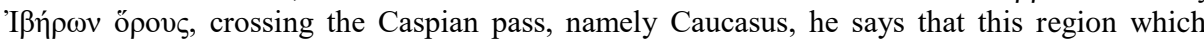

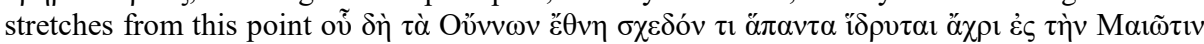

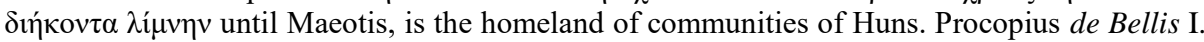
10. 1, 3, 6. After leaving the discussion of Procopius's expression of communities of Hun(s)

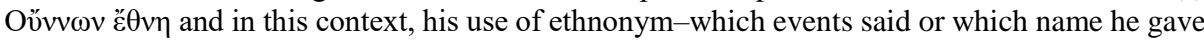
to the community in the situation-shows he tends to use the name Hun by making generalizations, it can be stated that he presents a view in accordance with Iordanes's depiction. About naming the peoples Hun in general, the peoples living in the east of the Sea of Azov this time towards the river Don, towards the north see Agathias Historiae V. 11. 2. 
then separates all three from each other. While it is understandable for the first two to be presented together because of both are north of Araxes, the fact that Seres, which is mentioned as in the east of Scythia in the second version, is included in the first version creates a new impression of inconsistency. This is not the only problem concerning Seres, who live by the Caspium Sea, inasmuch as, he declares them the only neighbor of Scythia on the east. The second case may be explained by his perception of Caspium as a part of the ocean. In that case, Iordanes may have imagined that Seres extends across the entire coast of Caspium in the east until the ocean in the north. If that is the case, as Seres are in the east, even in the Caspium and it can be border neighbors with Scythia, then the Caspium Sea must be a Scythian Sea. Our encountering Seres in unexpected places may not be related to the geographical perceptions of Iordanes but to a completely different reason. That is to say, Iordanes may not have wanted to be indifferent to the popularization of silk in Roman Empire in his own era, that is, in the era of Iustinianus. For this reason, he made Seres the neighbor of Scythia which he defined as a large and vast place, so he may have aimed to both strengthen his own definition of Scythia and offer an interesting neighbor to the reader. Probably the north of Scythia, in the eyes of Iordanes, forms the most indisputable and trouble-free border because he states that there is only the ocean there.

\section{Conclusion}

The Scythia narrative discussed in this study is scattered throughout Getica. This narrative appears in a chapter (Getica 30-37) devoted to the depiction of Scythia in Getica, as well as references made in various parts of the work when relevant, if not for the specific purpose of defining Scythia or any other place but to give information about a related topic. The topics which Iordanes deals with in his expressions about Scythia can be grouped under four headings: location, physical geography, historical geography, and human geography. There is something about all these four topics in the Scythia section (Getica 30-37). The section begins with the location of Scythia and a listing of the tribes who live there (human geography), while some physical geographical elements such as rivers are mentioned to describe both of them, including a depiction of the Caspian Sea; then the story of how these cities in Scythia are founded and what Huns once did here (historical geography) are stated. This section is included in Getica as an excursus. With the arrival of the Goths who are migrating to Scythia, the narrative of the Goth history is paused, the depiction of Scythia is given, after which the history of the Goths continues. However, the Scythia section given before and after this section does not coincide with the events he tells before and after these events. Before presenting the details of the Scythia adventure in the 
Goths' first and third phase of migration, Iordanes gives the impression to his reader that he wants to start by telling where this place is and by giving information about its situation in both his own and the reader's era. Of the Scythia topics seen in the other parts of Getica, the ones other than the title of historical geography, are also in the form of excursus. By comparison, it is quantitatively more substantial than the other subjects mentioned about Scythia in this section. However, the Scythia topics which Iordanes mentions as the space (place) of his history narrative or as it intersects with this narrative are far from presenting a holistic view, and are in the form of fragments of the author's perception of space.

The Scythia section does not give a definite idea about which of Iordanes' identities, his Christian, Goth, or Roman self, inspired him when creating his text. None of the three are included in the $6^{\text {th }}$ century Scythia panorama which he presents in the Scythia section and Iordanes does not show any signs of regret over their absence. He defines the general view of Scythia for both his era and before it as large, vast, prosperous, and not as barbaric, wild, and miserable. In order for a better understanding of Scythia and probably Getica in general, it is necessary to not imprison them into these templates and other types of generalizations. In addition, Iordanes' describing Getica as a summary introduces a unique issue for him. This is because, while interest in 'discovering' references, citations, and even plagiarism from classical texts is evident in the field of modern histography, Iordanes' characterizing Getica in this way instigated a search to 'discover' Cassiodorus behind every sentence. Even in quotations in which he openly cites other previous authors like Priscus, the possibility that he reached these authors via Cassiodorus is emphasized. Naturally, this perspective does not contribute much to understanding Iordanes himself and his literary work. At this point, the Scythia section can be evaluated as among the samples in which Iordanes's potential is revealed independent of Cassiodorus. In the Scythia section, he does not mention any literary sources, whereas before this section, he refers to travelers, he addresses rumors related to Gepidae, and beyond this, one sees that he points out oral sources about topics related to Scythia. Moreover, his being relatively silent about the eastern part of Scythia and his carelessness in positioning shows that he presents an authentic fiction and narrative in the Scythia section.

In both versions where Iordanes presents a holistic Scythia localization, it is understood that while describing, he uses not only neighbors who share borders like Germania and Vistula but also the ones around it, such as Araxes and Seres. Furthermore, in the first version, he describes Scythia's position with the elements inside and outside, while in the second version only in terms of outside elements. His aim of mentioning the ones around it while stating the location, may be to instill confidence in his characterization of Scythia as a vast land. His 
depiction of the east part of Scythia and for its border, his giving an uncertain position for Sabiri, even though he does not do so for Hunugiri, and indicating only Seres on the eastern border gives the impression that Iordanes has now come to an area which he cannot know much about and even cannot reach the information he needs. Also, it seems as if he avoided describing the eastern border as a whole and focused on the southeast border in both versions. His placing the Asian-European border in the middle of Scythia over Tanais requires that Scythia, whose west part stretches to the Vistula, be of symmetrical width to the east. However, the text is not consistent with this. These problems regarding the physical imagery of Scythia when it comes to the human depiction of geography must have left marks which were seen in Sabiri and Hunugiri samples. Despite presenting a human geography for Scythia which is lacking detail in the north and he northeast and is problematic in the east, we still see an authentic, intriguing depiction In Iordanes's Scythia one can encounter the following: Huns, the Huns themselves, advancing from the west to the east of Scythia for a hundred years from the mid $5^{\text {th }}$ century to the mid $6^{\text {th }}$ century to the Danube-the Black SeaCaucasians line and their shaping the region, the Bulgars replacing the Huns above the Black Sea; and their force, a tribe named Altziagiri; the Antes and Sclaveni, which appears in the northwest of the Black Sea, livestock farming, nomadism, trade, even marten trade and of course marshes and a transforming geography in terms of humankind.

Map recommendations:

For Ptolemaeus:

http://www.columbia.edu/itc/mealac/pritchett/00maplinks/early/mercator1578/ mercator1578.html

For historical maps in general and their reconstructions:

http://www.columbia.edu/itc/mealac/pritchett/00maplinks/early/early ind ex.html

For the forms of names in ancient ages engraved on the Word map:

https://dh.gu.se/dare/ 
Scythia as Reflected by Iordanes (Jordanes): A Scene from the Sixth Century

\section{BIBLIOGRAPHY}

\section{a. Sources}

Agathias Historiae see Keydell 1967; Frendo 1975.

Cassiodorus Variae $\quad$ see Mommsen 1894; Bjornlie 2019.

Iohannes Malalas see Thurn 2000; Jeffreys et al. 1986.

Iordanes Getica see Mommsen 1882; Mierow 1915; Gindin et al.

1991; Devillers 1995; Skrzhinskaiā2001.

Iordanes Romana see Mommsen 1882.

Marcellinus Comes Chronicon see Croke 1995.

Orosius Historia Adversus Paganos see Fear 2010; Tyulenev 2009.

Plinius Naturalis Historia see Rackham 1942.

Pomponius Mela de Chorographia see Brodersen 1994.

Priscus Fragmanlar see Blockley 1983.

Procopius Anecdota see Dewing 1940.

Procopius de Bellissee Dewing 1940; Kaldellis 2014.

Ptolemaeus Geographia see http://penelope.uchicago.edu/Thayer/E/Gazetteer/Periods/Roman/ Texts/Ptolemy/home $\underline{\text { html }}$

Sozomenus Historia Ecclesiastica see Unnamed 1851; Schaff et al. 1989.

Tacitus Germania see Hatapkulu 2006.

\section{b. Studies, Editions and Translations}

Blockley 1983, $\quad$ Roger C. Blockley, The Fragmentary Classicising Historians of the Later Roman Empire II Eunapius Olympiodorodus Priscus and Malchus text translation and historiographical notes. Liverpool: ARCA Classical and Medieval Texts, Papers and Monographs 10.

Bjornlie 2019, M. Shane Bjornlie, The variae: the complete translation Cassiodorus. California: University of California Press.

Brodersen 1994, Kai Brodersen, Pomponius Mela Kreuzfahrt durch die alte Welt, Darmstadt 1994.

Brodersen 2012, Kai Brodersen, "Cartography", in Daniel Dueck ve Kai Brodersen, Geography in Classical Antiquity. Cambridge: Cambridge University Press, p. 99-110.

Croke 1995, Brian Croke, The Chronicle of Marcellinus: a translation and commentary. Sydney: Australian Association for Byzantine Studies.

Curta 1999, $\quad$ Florin Curta, "Hiding Behind a Piece of Tapestry: Jordanes and the Slavic Venethi" Jahrbücher für Geschichte Osteuropas Neue Folge, Bd. 47, H. 3, p. 321-340. 
Curta 2001, $\quad$ Florin Curta, The Making of the Slavs History and Archaeology of the Lower Danube Region c. 500-700. New York: Cambridge University Press.

Curta 2019, “ $\quad$ Florin Curta, "Ethnicity in the Steppe Lands of the Northern Black Sea Region during the Early Byzantine Times", Archaeologia Bulgarica XXIII, I.

Çekil 2020, $\quad$ Okan Çekil, Marcellinus Comes Kronografyası ve Türk Tarihi. İzmir: Ege Üniversitesi Sosyal Bilimler Enstitüsü, unpublished master thesis.

Devillers 1995, Olivier Devillers, Histoire des Goths Jordanes introduction, traduction et notes. Paris: Les Belles Lettres.

Dewing 1940, Henry B. Dewing, Procopius with an English translation. The Loeb Classical Library. Cambridge: Harvard University Press.

Doncheva-Petkova 2014

Liudmila Doncheva-Petkova, "Ethnic Changes in Present-day Bulgaria in $6^{\text {th }}-9^{\text {th }}$ Centruries", in Ed. Doncheva-Petkova et al., Avars, Bulgars and Magyars on the Middle and Lower Danube, Sofia.

Fear 2010, Andrew T. Fear, Orosius Seven Books of History against the Pagans. TTH, Liverpool: Liverpool University Press.

Frendo 1975, Joseph D. Frendo, The Histories Agathias. Corpus Fontium Historiae Byzantinae v. 2 A, Berlin - New York: Walter de Gruyter.

Gindin et al. 1991, $\quad$ L. A. Gindin et al., Svod drevnershikh pis'mennykh izvestiŭ o slavianakh. tom I (I-VI vv), Moskva: Nauka.

Goffart 1980, Walter A. Goffart, The Narrators of Barbarian History. Princeton: Princeton University Press.

Gordon 2013, Colin D. Gordon, The Age of Attila: Fifth-Century Byzantium and the Barbarians. Foreword by Arthur E.R. Boak with a new Introduction and notes by David S. Potter. Ann Arbor: University of Michigan Press.

Jeffreys et al. 1986, Michael Jeffreys et al., The Chronicle of John Malalas. Melbourne: Australian Association for Byzantine Studies.

Kaçar 2018,

Kaldellis 2014, Turhan Kaçar, “Iordanes'i Nasıl Okumalıyı??”. XVII. Türk Tarih Kongresi, t. 1, Ankara: Türk Tarih Kurumu, p. 545-56.

Anthony Kaldellis, The Wars of Justinian Prokopios. Indianapolis: Hackett Publishing Company.

Kazanski 2013, M. Kazanski, "The land of the Antes according to Jordanes and Procopius" in Florin Curta, Bogdan-Petru Maleon (ed.) The Steppe Lands and the World Beyond Them: studies in honor of Victor Spinei on his 70th birthday. Iași: Editura Universității "Alexandru Ioan Cuza", 2013. 
Keydell 1967,

Harmatta 1951,

Hartog 1997,

Hatapkulu 2006,

Heather 2012,

Madgearu 1997,

Maenchen Helfen 1966

Maenchen-Helfen 1973

Merrills 2005,

Mierow 1915,

Mommsen 1882,

Mommsen 1894,

Moravcsik 1943,

Moravcsik 1958,

Pohl 2018,

Rackham 1942,

Schaff et al. 1989,
Rudolf Keydell, Agathiae Myrinaei Historiarum libri quinque. Corpus Fontium Historiae Byzantinae, v. 2, Berolini, De Gruyter.

János Harmatta, "The Golden Bow of the Huns" Acta Archaeologica, t. 1, p. 114-149.

François Hartog, Herodotus'un Aynast. Ankara: Dost Kitabevi. tr. Emin Özcan

Mine Hatapkulu, Germania Halklarının Kökeni ve Yerleşim Yerleri. İstanbul: Kabalc1 Yayınevi.

Peter Heather, Gotlar. Ankara: Phoenix. tr. Erkan Avc1.

Alexandru Madgearu, "About Lacus Mursianus (Jordanes, Getica, 30 and 35)", Byzantinoslavica, 58, 1, p. 87-89

\section{1, No. 4 (December 1966), p. 275-286}

Otto J. Maenchen Helfen, The World of the Huns studies in their history and culture. Berkeley: University of California Press.

Andrew H. Merrills, History and Geography in Late Antiquity. New York: Cambridge University Press

Charles C. Mierow, The Gothic History of Jordanes in English version with an introduction and commentary. Princeton: Princeton University Press.

Theodorus Mommsen, Iordanis Romana et Getica. Monumenta Germaniae Historica auctorum antiquissimorum t. 5, pars 1, Berolini: Apud Weidmannos.

Theodorus Mommsen, Cassiodori Senatoris Variae. Monumenta Germaniae Historica auctorum antiquissimorum t. 12, Berolini: Apud Weidmannos.

Gyula Moravcsik, Byzantinoturcica II Sprachreste der Türkvölker in den byzantinischen Quellen. Budapest: Kir. M. Pázmány Péter Tudomanányegyetemi Görög Filológiai Intézet. Gyula Moravcsik, Byzantinoturcica I Die byzantinischen Quellen der Geschichte der Türkvölker. Berlin: Akademie Verlag.

Walter Pohl, The Avars: A Steppe Empire in Central Europe 567-822. New York: Cornell University Press.

Harris Rackham, Pliny Natural History Volume II: Books 3-7. Loeb Classical Library, Cambridge: Harvard University Press.

Philip Schaff et al., A Select Library of Nicene and Post-Nicene Fathers of The Christian Church II Socrates, Sozomenus Church Histories. Edinburgh: T.\&T. Clark. 
Setton 1950,

Skrzhinskaiāí, 2001,

Thompson 2008,

Taaffe 2003,

Thurn 2000,

Tyulenev 2009,

Vaczy 1982,

Unnamed 1851,
Kenneth M. Setton "The Bulgars in the Balkans and the Occupation of Corinth in the Seventh Century", Speculum 25/4, p. 502-543.

E. Ch. Skrzhinskaia, $O$ proiskhozhdenii $i$ deìinīakh getov: Getica. Sankt-Peterburg: Aleteria.

Edward A. Thompson, Hunlar. Ankara: Phoenix. tr. Sibel Dinçel.

Robert N. Taaffe, "Coğrafi Ortam”, in D. Sinor (ed.), Erken $\dot{I}_{c}$ Asya Tarihi. İstanbul: İletişim, p. 33-59. tr. Mete Tunçay.

Ioannes Thurn, Chronographia Ioannis Malalae. Berolini: W. de Gruyter.

V. M. Tyulenev, Pavel Oroziy İstoriya protiv yaziçnikov pirivod s latinskavo kommentarii i ukazatel. Biblioteka Hristianskoy Misli, Sankt-Peterburg.

Peter Vaczy, "Hunlar Avrupa'da" in G. Nemeth (ed.), Attila ve Hunları. Ankara: Dil ve Tarih Coğrafya Fakültesi Yayınları, p. 51-122.

Tserkovnaya istoriya Ermiya Sozomena Salaminskovo. SanktPeterburg, Tipografiye Fishere. 